\title{
Effect of Nutrition, Lactation and Gonadotropin Stimulation on Ram-Induced LH Surge and Subsequent Fertility in Early Post- Partum Ewes during Seasonal Anestrous
}

Abiodun Emmanuel Adebiyi

Follow this and additional works at: https://researchrepository.wvu.edu/etd

\section{Recommended Citation}

Adebiyi, Abiodun Emmanuel, "Effect of Nutrition, Lactation and Gonadotropin Stimulation on Ram-Induced LH Surge and Subsequent Fertility in Early Post-Partum Ewes during Seasonal Anestrous" (2015).

Graduate Theses, Dissertations, and Problem Reports. 5029.

https://researchrepository.wvu.edu/etd/5029

This Thesis is protected by copyright and/or related rights. It has been brought to you by the The Research Repository @ WVU with permission from the rights-holder(s). You are free to use this Thesis in any way that is permitted by the copyright and related rights legislation that applies to your use. For other uses you must obtain permission from the rights-holder(s) directly, unless additional rights are indicated by a Creative Commons license in the record and/ or on the work itself. This Thesis has been accepted for inclusion in WVU Graduate Theses, Dissertations, and Problem Reports collection by an authorized administrator of The Research Repository @ WVU. For more information, please contact researchrepository@mail.wvu.edu. 
Effect of Nutrition, Lactation and Gonadotropin Stimulation on Ram-Induced LH Surge and Subsequent Fertility in Early Post-Partum Ewes during Seasonal Anestrous

\title{
ABIODUN EMMANUEL ADEBIYI
}

\author{
Thesis submitted to the \\ Davis College of Agriculture, Natural Resources and Design \\ at West Virginia University \\ in partial fulfillment of the requirements for the degree of \\ Master of Science in Reproductive Physiology
}

Marlon Knights, Ph.D., Chair

Ida Holásková, Ph.D

Matthew E. Wilson, Ph.D

Division of Animal and Nutritional Sciences

Morgantown, West Virginia

2015

Keywords: Ewe, Anestrous, Lactation, Gonadotropin, Feed Supplementation, Fertility Copyright 2015 Abiodun Emmanuel Adebiyi 


\title{
ABSTRACT \\ Effect of Nutrition, Lactation and Gonadotropin Stimulation on Ram-Induced LH Surge \\ and Subsequent Fertility in Early Post-Partum Ewes during Seasonal Anestrous.
}

\begin{abstract}
Abiodun Emmanuel Adebiyi
This study evaluated the effect of lactation, exogenous gonadotropin (GS), and nutritional supplementation (SUPP) on fertility of Katahdin ewes during seasonal anestrous. Experiment 1 evaluated effects of lactation and GS on ram-induced LH surge. Lactating (65 to $80 \mathrm{~d}$ postpartum; pp) and dry ewes were randomly assigned to be treated with an estrus induction protocol (EIP) consisting of a 5-d treatment with a CIDR device with an injection of a gonadotropin mixture (240 IU eCG and $120 \mathrm{IU}$ hCG; P.G. 600®; $3 \mathrm{ml} /$ animal i.m.; $\mathrm{n}=16$ ) or no further treatment $(n=16)$ at removal of CIDRs. Experiment 2 was similar to experiment 1 and evaluated the specific effects of lactation and GS on the ram-induced LH surge and subsequent fertility. Lactating (approximately $68.7 \pm 1.3$ days $\mathrm{pp}$ ) and dry ewes were treated with CIDR device with $(n=42)$ or without $(n=38)$ an injection of the gonadotropin mixture. In Experiment 3 , effects of both levels of nutritional supplementation and GS on fertility of lactating ewes were evaluated. Lactating ewes $(n=87)$ on pasture, were assigned randomly and then balanced for litter size to receive either a low or high amount of grain supplementation (13.3\% Crude Protein; $\mathrm{CP}$; $0.68 \mathrm{~kg}$ or $1.14 \mathrm{~kg} / \mathrm{d} /$ animal; equivalent to 30 and $50 \%$ of projected Dry matter intake; DMI, respectively) from 1.5 to 2.5 months postpartum and then treated with CIDR for 5 days with or without GS at CIDR removal. Analysis of Variance (ANOVA) was used to evaluate the main effects and their interactions on response variables. In experiment 1, the proportion of ewes with a detectable LH surge was greater $(\mathrm{P}=0.0001)$ in ewes treated with EIP with an injection of gonadotropin mixture, but there was no effect of lactation status. In experiment 2 , the mean proportion of ewes with detectable LH surge tended to be higher in ewes receiving GS than in ewes not receiving GS ( $\mathrm{P}=0.07 ; 87.1 \%$ vs $57.2 \%$, respectively). Estrous response was higher in ewes receiving than in ewes not receiving GS $(\mathrm{P}=0.0045 ; 63.9 \%$ vs $38.6 \%$, respectively) with no effect of lactation status. GS tended to increase estrous response in lactating but not dry ewes (LACT x GS, $\mathrm{P}=0.1$ ). Conception and pregnancy rates were lower in lactating ewes compared to dry ewes $(\mathrm{P}=0.0172,0.0131)$. In Experiment 3 , estrous response was greater in ewes receiving than in those not receiving GS $(P=0.009 ; 67.4 \pm 7$ and $33.6 \pm 7 \%$, respectively) and tended to be greater in ewes receiving the high vs. low level of supplementation $(P=0.10 ; 58.6$ \pm 8 and $42.3 \pm 6 \%$, respectively). The pregnancy rate (PR) was increased by GS $(P=0.003 ; 49 \pm$ 7 and $19.9 \pm 7 \%$, for ewes receiving and not receiving GS, respectively) and by increasing the amount of supplement $(P=0.05 ; 43.8 \pm 8$ and $25.1 \pm 6 \%$, for ewes receiving the high and low level of supplementation, respectively). The interaction of GS and nutritional supplementation was not significant for any of the variables measured $(\mathrm{P}>0.1)$. The mean peak concentration of LH and time to peak concentration in ewes with detectable LH surge were not affected by any treatment in this study. In conclusion, during anestrous, early postpartum fertility is reduced by lactation in Katahdin ewes, but fertility in lactating ewes can be restored to that of dry ewes with nutritional supplementation and by providing exogenous gonadotropin as part of an EIP.
\end{abstract}




\section{TABLE OF CONTENTS}

Abstract.............................................................

Table of Contents.......................................................

Acknowledgments..................................................

List of Tables.................................................... vi

Review of Literature ................................................

Sheep Industry in the United States.............................

Seasonality of Sheep Reproduction...................................

Endocrine Regulation of the Estrous Cycle..........................4

Expression of Seasonality in the Ewe...........................6

Expression of Seasonality in the Ram............................8

Environmental Factors Controlling Seasonality......................9

Photoperiod as a Principal Factor........................... 9

Environmental Temperature as a Modulating Factor..............11

Nutritional Status as a Modulating Factor.....................13

Lambing Date as a Modulating Factor.......................16

Social Interactions as Modulating Factor....................16 
Means of Overcoming Seasonality in Ewes.

Ram Effect..................................................20

Use of Exogenous Hormones.................................23

Effect of Lactation on Ewe fertility .................................28

Effect of Weaning on Lamb Growth and Survival.......................31

Problem Statement.......................................................... 34

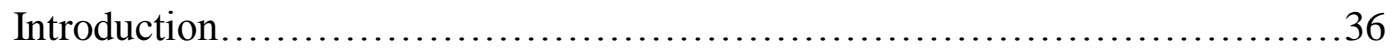

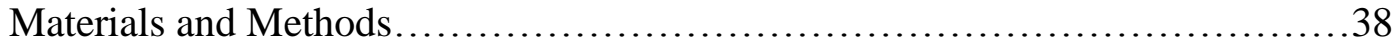

Results............................................................ 42

Discussion.......................................................57

Implications.....................................................61

References........................................................62

Vita................................................................ 89 


\section{ACKNOWLEDGMENTS}

First and foremost, I wish to express my sincere gratitude and appreciation to my advisor, Dr. Marlon Knights for his unwavering support, advice, and encouragement, assistance throughout my degree program, the opportunity to embark on this project and for believing in my ability. The lessons I have learnt are forever engraved in my heart.

My sincere gratitude is also extended to Dr. Holásková and Dr. Wilson for accepting to and for serving on my committee, and for their precious time and positive insights. My appreciation has no bound.

I would also like to thank my lab members, both in the past and present; Kellie D'Souza, Adam Redhead, Calli Paul, Stephanie Simpson, Kyle Powell, Erin Keller and Sarah Carr, Natalia Ribeiro and some other colleagues, most importantly Karen Sommer and Jessalyn Hadfield, for their support, help, perseverance and cooperation during the "marathon" bleeding and other data collections without which this study would have been unsuccessful. I am forever indebted to you.

I would also like to thank Jerry Yates, Chestina Merriner and the rest of the Farm Crew at Reymann Memorial Farm, Wardensville for their humane treatment, hospitality and support. Also, my appreciation goes to Dr. Robert Goodman, Dr. Miroslav Valent, Gail Nesselrod and Rick McCosh for their help on the LH analysis. Thanks for the support.

I also appreciate the consistent moral, emotional and financial support from my family and friends; and above all, my utmost and sincere appreciation goes to God Almighty for the strength, ability, divine help and grace throughout the course of this academic endeavor. 


\section{LIST OF TABLES}

Table 1. Effect of lactation and gonadotropin stimulation on characteristics of the ram-induced LH surge and pregnancy...................................... 44

Table 2. Effect of level of nutritional supplementation and gonadotropin stimulation on

characteristics of the ram-induced LH surge and pregnancy........................... 45 


\section{REVIEW OF LITERATURE}

\section{Sheep Industry in the United States}

Over the last 5 decades, the prevalent feature of the sheep industry in the United States (US) has been a steady decline in sheep and lamb inventories. This has been a major issue of concern and focus for the producers and policymakers alike. The decline in sheep and lamb numbers has created difficulties in the flow of sheep and lamb products through a shrinking marketing system as producers have struggled to respond to market signals while maintaining profitability (BANR, 2008).

The market for sheep products has shifted from wool to meat so as to meet the increasing consumption of lamb and as a response to low wool prices and lower cost of synthetic fibers which made them more attractive to the consumers (Jones, 2004). Also, the increase in demand for lamb has been inelastic as a result of low supply which is due to decreased imports and expansion in the cultural and ethnic market, and buying habits which have shifted from its dependency on price to the quality of the product (Dumas, 2011).

However, several factors have contributed to the decline in the sheep inventory. These factors include but are not limited to low lamb prices, low lamb consumption when compared to other meats, limited success of attempts to promote and differentiate U.S lambs from other meats and, increasing disease and predator losses (Jones, 2004).

In an attempt to address the declining sheep inventory, the American Sheep Industry (ASI) Association developed and implemented the "Let's grow program". The goal of this initiative is 
to encourage sheep producers to improve production efficiencies in light of the high cost of feed, fuel and other costs of production in order to sustain and expand the sheep industry.

In a recent report by National agricultural Statistics Service (NASS), the inventory of all sheep and lambs in the US (5.28 million) increased by $1 \%$ (35,000 head increase) from 2014-2015. This increase in breeding animals included a 15,000 head increase in replacement lambs that are under 1 year of age. This is expected to maintain a tight lamb and mutton supply and consequent inflation in the price (Mathews and Haley, 2015) since these sheep that can be sent to slaughter need to be recruited for breeding. As a result, there is still a need for increasing production efficiency in the sheep industry.

In summation, the United States sheep industry has experienced a significant decline in sheep inventory. Presumably, the decline in production is due to a number of factors, such as low profitability of sheep enterprises, increased competition in demand between markets, loss of animals due to predation and parasitism, and low productivity of ewes. Attempts to increase productivity of the ewe and in particularly, increase the frequency of lambing are hampered by the seasonal nature of reproduction in the ewe. Attempts to shift the seasonal pattern of reproduction have been partially successful, but the lambing rate is still lower than is observed during the breeding season, and limited success has been realized from attempts to breed lactating ewes during anestrus. Approaches that enhance the fertility of ewes bred out-of-season can further increase profitability of producers, leading to increased production and revitalization of the sheep industry (Reviewed by D'Souza, 2013). 


\section{Seasonality of Sheep Reproduction}

The seasonality of reproduction is an adaptive physiological process utilized by wild animals to cope with seasonal changes in temperature and food availability, that is, breeding is initiated when the environment will allow for the best survival of the young. The reproductive patterns of an animal are a consequence of the interaction of the endogenous regulatory mechanisms mainly endocrine- and environmental signals. These signals may affect reproductive mechanisms, that is, estrous cycles can cease to occur in some periods of the year in females or they can ovulate and come into estrus during the seasonal non-cycling period due to the acute stimulus of male presence (Ungerfeld and Bielli, 2012).

Although seasonality is almost completely lost in cattle and pigs due to domestication, it is retained in most breeds of sheep, goats and horses originating from temperate latitudes (Malpaux et al., 1996). The annual cycle of daily photoperiod is the determinant factor of onset and duration of breeding seasons while environmental temperature, nutritional status, social interactions, lambing date and lactation are considered as modulating factors (Rosa and Bryant, 2003). The timing of the breeding season is dependent on the length of the gestation period so that parturition occurs in the spring, which is the optimal season for nourishment and survival of the young. Thus, sheep and goats with 5 month gestations are short-day breeders with conception occurring in autumn and winter, whereas horses which have an 11 month pregnancy, are most fertile during the long days of spring (Ortavant et al., 1985). 


\section{Endocrine Regulation of the Estrous Cycle}

The estrous cycle is defined as the number of days between the start of two different periods of estrus, or heat (Kennedy, 2012). A complex regulatory system involving a number of hormones controls the estrous cycle (see figure 1). According to Karsch and Moenter (1990), the hypothalamus secretes GnRH into blood vessels that flow to the anterior pituitary (AP). GnRH acts on specific cells of AP to release FSH and LH which are transported to the ovaries to prompt follicular development. As the follicles grow, LH and FSH act synergistically on the follicles to stimulate secretion of estradiol $\left(\mathrm{E}_{2}\right)$, which increases as the maturing follicles get larger. The $\mathrm{E}_{2}$ has a positive and negative feedback on hypothalamus and AP to control release of FSH and LH (Legan and Karsch, 1980, Karsch et al., 1984) and a peak in the blood concentration of $\mathrm{E}_{2}$ results in the secretion of large quantity of LH (pre-ovulatory LH surge), which is responsible for rupture of follicle and release of ovum; the ovulation (Thomas et al., 1988). The principal peaks of FSH in plasma have also been shown to coincide with the pre-ovulatory rise the level of LH (Foster et al., 1975). After ovulation, LH transforms follicle into a corpus luteum (CL) which secretes progesterone (P4). As $\mathrm{LH}$ stimulates the CL to secrete $\mathrm{P}_{4}$, the increasing $\mathrm{P}_{4}$ has negative feedback on hypothalamus to decrease GnRH production and consequently on AP to decrease FSH and LH secretions (Skinner et al., 1998). This may reduce follicular growth and suppresses estrus and ovulation as long as the progesterone level is high.

Progesterone is the major hormone that supports and maintains gestation as it plays a major role in the preparation of the reproductive tract for pregnancy. If there is no conception, $\mathrm{PGF}_{2 \alpha}$ produced by the uterus then causes the regression of the corpus luteum and lowers the level of plasma $\mathrm{P}_{4}$ (McCracken et al.,1970; McCracken et al, 1972; Inskeep and Murdoch, 1980). The decrease in $\mathrm{P}_{4}$ signals the end of luteal phase and the start of the new follicular phase as the 
hypothalamus begins to produce GnRH. However, if conception occurs, the CL persists and continues the secretion of $\mathrm{P}_{4}$ to maintain pregnancy throughout the period of gestation (Spencer et al., 2004; 2007).

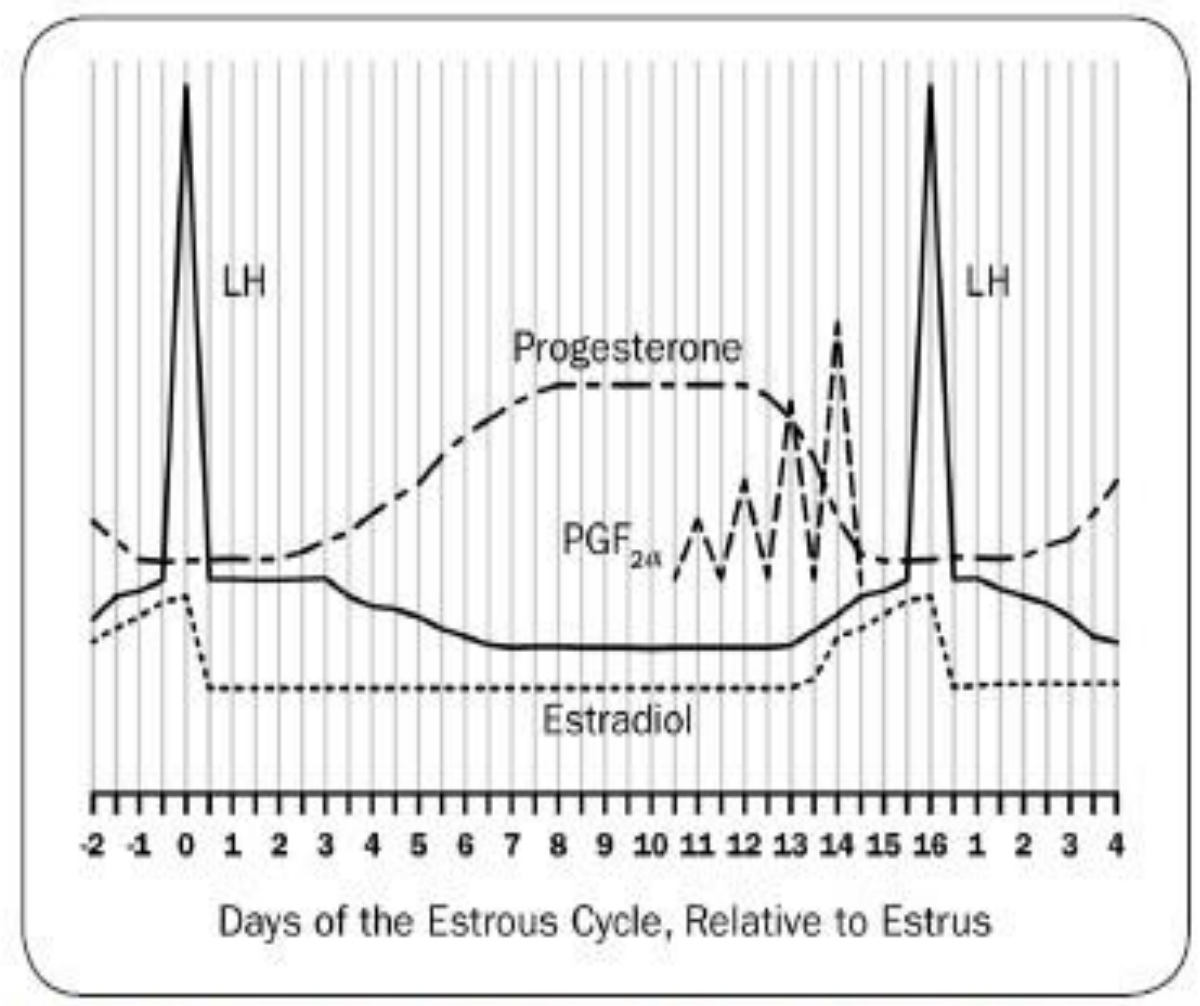

Figure 1. Estrous cycle. Sheep Production Handbook (2002). 


\section{Expression of Seasonality in the Ewe}

Reproductive seasonality in the ewe is characterized by behavioral, endocrine and ovulatory changes which give rise to an annual alternation between two distinct periods; a breeding season which is characterized by the succession at regular intervals (mean of 17 days) of estrous behavior and ovulation in the non-pregnant ewe, and an anestrous season characterized by the cessation of sexual activity. The transition from anestrus to breeding season is gradual, with the occurrence of shortened estrous cycles. These short estrous cycles occur due to premature regression of the corpus luteum (CL), 5-6 days after its formation. Both ovulatory activity and estrous behavior show parallel seasonal variation but there are some discrepancies at the beginning and at the end of the sexual season when some ovulations are not accompanied by estrus. It is only after the end of the first ovarian cycle that the behavioral estrus is exhibited (Rosa and Bryant, 2003). In some breeds, silent ovulations, which are not related either to the onset or the end of the sexual season, may also occur during mid-anestrus (Land et al., 1973; Ortavant et al., 1988).

It is clearly evident that the difference between breeding and non-breeding season is brought about by the frequency of GnRH pulses, which is substantially reduced during anestrous season as compared to the breeding season (Goodman et al., 1982; Robinson et al., 1985; Barell et al., 1992; Karsch et al., 1993). During the last oestrus cycle of the breeding season, the regression of the CL is not followed by a GnRH surge and ovulation (Legan and Karsch, 1979), and there is an increase in the frequency of GnRH pulses during the transition from anoestrus to the breeding season (Legan et al., 1977). 
The control of seasonal breeding is thought to be caused by a marked seasonal shift in the response of the hypothalamus to estradiol, such that estradiol has negative feedback action on the hypothalamus and anterior pituitary during anestrous and positive feedback during the breeding season (Goodman et al, 1982; Legan and Karsch, 1979; Platt et al., 1983). In ovariectomized ewes that were treated with estradiol (released at constant levels via implant) at mid-luteal phase, LH levels were constantly high during the breeding season ( $\mathrm{LH}>5-10 \mathrm{ng} / \mathrm{ml}$ ) but maintained basal levels during the anoestrus season (Karsh et al., 1980). This is further supported by other studies in which continuous release of LH was observed, but with lower frequency during the anestrous than during the reproductive season. For example, one pulse every 8-12 hours is observed during anestrus compared to one pulse per 3-4 hours in the mid-luteal phase, one pulse per 1-2 hours immediately prior to the preovulatory LH surge and one pulse every 20 minutes during the preovulatory LH surge (Martin, 1984; Thiéry and Martin, 1991).

Follicle growth and regression continue during anestrous season and follicles as large as those found during the luteal phase of the oestrus cycle can be observed (Hutchinson and Robertson, 1966; Matton et al., 1977; Webb and Gauld, 1985). The follicles produce steroids throughout seasonal anoestrus and many of the positive and negative feedback effects of the steroid on secretion of luteinizing hormone (LH) continue as in the breeding season (Gordon, 1997).

The plasma concentration of progesterone remains virtually undetectable during anoestrus (Roche et al., 1970; Karsch, 1984) and there seems to be no significant change in the level of follicle stimulating hormone (FSH) from those found during the reproductive season (Goding et al., 1969; Roche et al., 1970; Walton et al., 1977). According to Gonzalez-Bulnes et al. (2000), in the ewe, seasonality can be measured by the change in weight of the ovaries all through the 
year as a result of the presence or absence of corpora lutea and the variation in the number of follicles which modify the types and levels of steroid hormones secreted.

\section{Expression of Seasonality in the Ram}

In Rams, seasonal variation has been reported in sexual behavior, testicular weight and volume, hormonal activity and gametogenesis (Schanbacher and Lunstra, 1976; Lincoln and Davidson, 1977; Ortavant et al., 1985; Gundogan et al., 2002). Behavioral and physiological variations are less pronounced in the ram than in the ewe. Continuous spermatogenesis and sexual activity are observed in the ram while ovulation and estrus is arrested in the ewe. Spermatogenesis and sexual activity are low at the end of winter and during spring but high at the end of the summer and during fall (Lincoln and Short, 1980; Haynes and Schanbacher, 1983; Pelletier and Almeida, 1987).

Sexual activity in Rams is stimulated 1- 1.5 months earlier than in ewes to allow rams to achieve a high level of sexual activity at the time when the cyclic period of the ewes starts. This is said to be important because while anestrous ewes can ovulate within a few days after hormonal stimulation due to the ever-present large-sized follicles, the ram needs approximately 45 days to complete spermatogenesis (Rosa and Bryant, 2003).

Lincoln and Davidson (1977) reported an increase in LH and FSH concentration in Soay rams 24 weeks after the abrupt change from long (16h light : $8 \mathrm{~h}$ darkness) to short days (8h light: $16 \mathrm{~h}$ darkness) followed almost immediately by a rise in plasma testosterone levels and testicular growth. 


\section{ENVIRONMENTAL FACTORS CONTROLLING SEASONALITY}

\section{i. Photoperiod as a Principal Factor}

Photoperiod is the duration of light exposure within a 24-hour day. A long day photoperiod (LDPP) consists of a 16- to 18-hours of light exposure and 6- to 8-hours of darkness while the short day photoperiod (SDPP) is characterized by 8 hours of light exposure followed by 16 hours of darkness. Photoperiodicity is the physiological reaction of organisms to the length of day or night.

Photoperiod regulates cyclicity in seasonal breeders (Hamadani et al., 2013). There is transduction of photoperiodic information into neuroendocrine changes through variations in melatonin secretion from the pineal gland. In ewes, melatonin triggers variations in the secretion of GnRH responsible for seasonal changes in their reproductive activity (Thiery et al, 2002). Dahl et al. (2000) reported that there is a correlation between photoperiod and secretion of melatonin from the pineal gland, such that circulating melatonin is nearly absent during exposure to light but rapidly increases upon exposure to darkness.

Melatonin is a modified amino acid which is synthesized from serotonin and its secretion is mainly by the pineal gland, with secondary secretions by the retina, skin, bone marrow, blood platelets, gut and probably other structures, with little or no significant systemic contribution (Liu et al., 2004). The solubility of melatonin in lipid and water allows its passage across cell membranes (Pardridge, 1980). It therefore gains access to bodily fluids, tissues and cellular compartments (cerebrospinal fluid, urine, saliva, preovulatory follicle, amniotic fluid, semen and milk ) after its release in the circulation, and passes across information about the lighting of the environment to various parts of the body (Hamadani et al., 2013). 
The melatonin rhythm is associated with the dark hours of the day with the photic information transmitted to the central pacemaker through the retino-hypothalamic fibers. During the day, the photic information from the retino-hypothalamic tract inhibits melatonin synthesis due to the presence of light (Hamadani et al., 2013). In an earlier study, Lewy et al., 1980 reported that melatonin production was suppressed when artificial light of sufficient intensity and duration was administered at night.

The melatonin signal was reported to be a viable regulator of neuroendocrine state that can turn on or off the reproductive axis of pinealectomized animals treated with infusion of melatonin repeatedly administered in the night. This mimics the pattern of its secretion typical of long or short photoperiods. The same melatonin signal leads to opposite neuroendocrine responses in spring-breeding species, since a progressive decrease in the duration of the night-time melatonin signal results in reproductive activation as days lengthen in the spring (Johnson, 2007).

Melatonin enhances GnRH synthesis in sheep, so sheep are short day breeders (fall breeders). Rams are also affected by photoperiod but to a lesser extent than in the ewes. In ram, there is decrease in sperm production, increase in abnormal spermatozoa and decreased fertility as photoperiod increases in the spring and early summer. In ewe, there is inactivity of the ovaries, absence of both dominant follicles and behavioral estrus (Senger, 2003).

The site or pathway of action of the effect of melatonin is still unknown. Melatonin binding sites are preferentially localized in the pars tuberalis (PT) of the adenohypophysis, which suggests that this may be the site of action; however the direct delivery of melatonin into the PT does not influence LH secretion. In contrast, melatonin delivered in the mediobasal hypothalamus mimics the effects on LH secretion of peripherally administered melatonin. This suggests that, despite 
the presence of high melatonin binding in the PT, the mediobasal hypothalamus contains the physiological target site of melatonin actions on LH release. The action of melatonin on LHRH secretion appears to involve a complex circuit of interneurons and does not seem to be directly on LHRH neurons (Malpaux et al., 1996).

Dardente (2011) reported evidence for a circadian-based molecular mechanism within the pars tuberalis of the pituitary, which links the short duration melatonin signal of the long day length to the hypothalamic increase of triiodothyronine (T3) through a thyroid-stimulating hormone/ deiododinase- 2 paracrine mechanism. This implied that the mechanisms of T3 action within the hypothalamus are pertinent to seasonal timing.

Irrespective of the mechanism and site of action of melatonin, its administration either by daily dosing or through constant-release devices allows short days to be mimicked and therefore it can be used to control the seasonal reproduction in both the ram and the ewe (Rosa and Bryant, 2003). However, Chemineau et al. (1992) reported that for the treatment to be effective the animals must have been exposed to long days prior to receiving the melatonin. The duration of treatment with melatonin necessary to induce ovulatory cycles was reported as 14-21 and 40-60 days for rams and ewes, respectively (Haresign, 1992).

\section{ii. Environmental Temperature as a modulating Factor}

Environmental temperature plays an important role in reproductive activity as one of the modulators of the photoperiod effect on seasonality. However, environmental temperature cannot impose seasonality on reproductive activity of the ewe. Wodzicka-Tomaszewska et al. (1967) found that the annual rhythm of reproduction persisted in ewes kept under a constant photoperiodic schedule of 12 hours of light-12 hours of dark daily despite the dramatic changes 
in temperature. Jansen and Jackson (1993) reported that photoperiod length does not influence the expression of circannual reproductive rhythm where episodic variations in ovarian cycle density were observed in 2 groups of ewes (ewes kept under 12 hours of light - 12 hours of dark and in those kept under 8 hours of light-16 hours of dark in a photo-chambers) under restricted temperatures. The period of circannual rhythm was similar in both groups and episodic variations in ovarian cycle density were observed in most ewes in both groups despite temperature changes within the photo-chambers where the ewes were housed. Therefore, the likely explanation is that temperature changes play a permissive role in the expression of circannual reproductive rhythms in the sheep. Temperature fluctuations may therefore serve to complete the series of stages necessary for full expression of a circannual rhythm of breeding and nonbreeding seasons in the ewe.

However, temperature might modify the onset of breeding season. Gundogan et al., (2003) reported that lowering the environmental temperature for sheep has given mixed results- earlier onset of breeding activity is favored by general protection of the ewe from high summer temperature while extremely low temperature may delay or shorten the breeding season. Ewes maintained under low temperatures during the summer period began their reproductive season earlier than those kept under temperatures typical of that season (Dutt and Bush, 1955; Godley et al., 1966), and a positive correlation was also found between mean temperature in July and the date of the onset of the breeding season in Clun ewes (Lees, 1966).

High temperature has been known to also affect fertilization, embryo survival and fetal size in sheep. Dutt (1954) and Hulet et al. (1956) reported frequently occurring morphological abnormalities in ova early in the breeding season of sheep. The primary ovum abnormalities 
noted with exposure to high temperatures have been shrunken cytoplasm, enlarged cytoplasmic globules or vacuoles, ruptured vitelline membranes or ruptured zona pellucida.

Heat stress can affect fertility in ewes. Dobson et al. (2012) reported that heat stress can have a disruptive effect on endocrine interactions to cause a suppression of the GnRH and consequently the frequency and amplitude of LH pulse. Their study showed that heat stress can delay the onset of estrous behavior and increase the interval between estrus and onset of the pre-ovulatory LH surge. In rams, prolonged exposure to high temperatures can result in lack of libido and further lower sperm quality (Schoenian, 2011). As the anestrous period coincides with the summer, the high temperatures at this time and associated heat stress can lower fertility in ewes that might have spontaneous ovulations at this time or in ewes induced to breed out of season.

\section{iii. Nutritional Status as a modulating Factor}

Nutrition is considered a very important factor influencing reproductive function and the effects of nutrition is regulated through several hormonal signals such as leptin, insulin and growth hormone (Rosa and Bryant, 2003). In the Mediterranean or tropical climates, nutritional level is probably responsible for some seasonal acyclicity. However, Gordon (1997) concluded that nutritional level appears to have little effect on the onset and duration of the breeding season in both temperate and tropical breeds.

The mechanisms involved in the regulation of reproductive processes by nutrition are complex and not clearly known (Smith, 1991; Robinson, 1996). However, some studies supported the hypotheses that nutrition affects the release or clearance of gonadotropins, the clearance of progesterone, and changing the degree of response of ewes to the inhibition of estradiol and inhibin by balancing FSH secretion and gonadal feedback; these reports are based on its effect on 
ovulation rate (Adams et al., 1997), pregnancy rate (Parr, 1987) and seasonality of reproduction (Boukhliq et al., 1996) respectively.

Live weight is influenced by nutrition and it has been established that ewes with higher live weights have increased fertility, higher ovulation rate, earlier onset of puberty and higher rate of embryo survival (Smith 1991; Robinson, 1996; Scaramuzzi et al., 2006; Ferguson et al., 2011). Poor performance in ewe lambs is said to occur at a live weight below $35 \mathrm{~kg}$ at breeding while a better performance is seen above 40-45kg (Allison et al., 1975; Gaskin et al., 2005; Kenyon et al., 2005). In a study to explore the effects of nutrition on birthweight and survival of merino lambs, Oldham et al. (2011) reported an increased birthweight and survival rate of the progeny as a result of improved feeding regimen during pregnancy.

In a study carried out by Forcada et al., (1992) in Rasa Aragonesa ewes, it was reported that there is a consistent reduction in the duration of seasonal anoestrus in ewes maintained at a constant and moderately high body condition score of 2.7 and higher compared to ewes maintained at a constant lower body condition score of 2.5 and lower for two consecutive years. Also, body condition score of 2.0 to 4.0 has been said to increase the proportion of singlebearing to multiple-bearing ewes and increase conception rate in ewes during seasonal anestrous so as to achieve a higher fecundity (Gonzalez et al., 1997). These findings suggest that the duration and or depth of seasonal anestrous can be reduced in ewes that have a moderately high level of fat reserves (Forcada and Abecia, 2006).

Nutrition has been reported to influence the onset of ovarian cyclicity in postpartum ewes (Restall and Starr, 1977). The effect of nutrition on sexual activity is minimal compared to its effect on ovulation rate but severe malnutrition can cause a significant extension in the length of 
seasonal anoestrous period, attributable to an earlier end of the reproductive season (Knight et al., 1983a).

In a study to determine if there is a central interaction between photoperiod and nutrition, Île-deFrance ewes maintained on a restricted state (low nutritional status) had a shorter season of ovarian activity than those maintained in a well fed state (high nutritional status) due to modification in the timing of seasonal transitions between periods of ovarian activity and anestrus (Menassol et al., 2012).

Brown (1994) reported that reproductive function in young male animals seems to be more susceptible to dietary restrictions of energy and protein as severe feed restriction may cause permanent gonadal and neural tissue damage while in adults, restriction in feed intake can cause a reduction in androgen secretion and semen quality which is restorable by re-feeding previously underfed adults.

In rams, changes in nutrition lead to profound responses in testicular size; therefore the rate of sperm production largely due to changes in the size of the seminiferous tubules and the efficiency of spermatogenesis. Gonadotropin secretion is affected for only a few weeks in case of a moderate change of nutrition but testicular growth is affected for several months (Martin and Walkden-Brown, 1995).

Ram on higher planes of nutrition reach puberty at a younger age and heavier body weight as compared to those on lower plane of nutrition (Ragab et al., 1966) with delayed testicular descent, penile development and appearance of spermatozoa in the ejaculate in the latter (Pretorious and Marincowitz, 1968). According to Hotzel et al. (1997) part of the effect of nutrition on testicular growth in ram is independent of changes in $\mathrm{GnRH}$ secretion as differences 
in the testicular growth induced by dietary treatment (lupin grain supplementation) in rams immunized against GnRH were not associated with changes in gonadotrophin or testosterone secretion.

\section{iv. Lambing Date as a modulating Factor}

Lambing date can also influence the seasonality of reproduction in sheep. An early lambing date is associated with an early onset of the subsequent breeding season. In a study to determine the effect of lambing date on the subsequent breeding season, Mitchell et al. (1997) reported that the onset and duration of ovarian activity but not its cessation were significantly affected by the previous lambing date,. According to this author, the mean dates of onset of ovarian activity for January and May lambing ewes were 5 September and 25 September while those of cessation were 5 April and 10 April, with the number of the ovarian cycles been 12.4 (s.e. 0.29 ) and 11.5 (s.e. 0.38), respectively. Lactating ewes that lambed in August, September and October recorded higher estrus rate than those that lambed in November and December when exposed to teaser rams for estrus detection 1-2 hours daily throughout the year (Hashem et al., 2011)

\section{v. Social Interactions as modulating Factor.}

The social interaction within a group of animals of the same species can affect various reproductive processes. In sheep, social interactions have been found between and within sexes such as male to male, female to female and male to female interactions.

In a male to male interaction, the sexual performance of future mature rams can be dependent on the social environment under which the ram lambs are reared. Rearing of rams in all male groups may increase the likelihood of male-male interaction and hinder or cause a delay in the development of sexual interest in females (Hulet et al., 1964, Price et al., 1988). Further, 
separation of ram lambs from the ewe lambs between 3 and 6 months of age causes a delay in the occurrence of first copulation (Orgeur and Signoret, 1984). Maina and Katz (1997) showed that the sexual performance of rams may be enhanced by exposing them to a ram that has recently mated a ewe in estrus. It is thought that this effect is due to olfactory cues associated with mating. However observing courtship mating behaviors of other rams does not improve the sexual performance of the observing ram (Price et al., 1991).

In female-female interaction, the sudden introduction of ewes in estrus to seasonally anoestrus ewes can induce and synchronize ovulation in the anoestrus ewes and thereby bring about an early onset of the breeding season (Muir et al., 1989; Zarco et al., 1995), so also the continuous presence of cyclic ewes will elucidate same effect (O'Callaghan et al., 1994; Nugent and Notter, 1990). On the other hand, the exposure to non-cyclic female flockmates has no effect on the reproductive state of anoestrous ewes (Donovan et al., 1991).

In male-female interaction, Rosa et al., (2000) reported that exposure of rams to both oestrus and anoestrus ewes brought about an increased level of sexual activity and elevated serum testosterone concentration in the rams, with highest response found in experienced rams stimulated by sexually receptive ewes (Gonzalez et al., 1991). This phenomenon is referred to as the 'female effect'. The 'female effect' is more evident during the anestrous season and when ewes are introduced to the rams at sunrise as compared to noon (Gonzalez et al., 1988).

The ram lambs reared with the ewes during the 'adolescence phase' of development and learning, which is the period between weaning and puberty as defined by Orgeur and Signoret (1984) exhibited enhanced sexual performance while ram lambs that were isolated from ewes during this developmental phase showed abnormal and delayed male mating behavior as adults. 
Also, according to Illius et al. (1976), yearling rams exposed to oestrus ewes for a period of 6 months have larger testes, higher plasma testosterone and greater sexual activity in contrast to rams isolated from ewes. However, the fact that contact with ewes by the ram lambs during rearing resulted in an improved sexual performance does not imply a successful elimination of rams with sexual orientation directed solely towards other rams (Zenchak et al., 1981, Price et al., 1988).

On the other hand, the continuous exposure of rams to ewes can have a regulatory effect on the ovarian activity in the ewes. Ewe lambs kept close to rams for 1.5 to 2 months before ovulation had their first ovulation earlier than ewes isolated from the rams (Al-Mauly et al., 1991).

The acute effect of ram introduction on the seasonally anovular ewes which brings the ewes into ovulation and estrous during late anestrous or early oestrous season is referred to as 'Ram effect' (Rosa and Bryant, 2002). The effect of rams to stimulate ewes is primarily mediated by pheromones which are released by the rams (Signoret, 1991) and acts in conjunction with other behavioral stimuli exhibited by the rams. On the other hand, the ewes have sensory cues such as smell, sight, sound and touch which can be used individually for optimum effect or synergistically to achieve a maximum effect in the perception of the stimuli (Rosa and Bryant, 2002).

Watson and Radford (1960) initially documented the effect of various level of relationship between the rams and ewes and concluded that odor and sound from the rams were enough to stimulate the ewes while sight and touch were not of necessity in inducing the response. Furthermore, a study on ewes with different sensory cues ablated showed a reduction in the oestrous response of the group of ewes with impaired sense of smell as compared to other 
sensory cues which suggested that oestrous response is stimulated by the rams via olfactory cues (Morgan et al.,1972).

Knight and Lynch (1980) demonstrated the presence of pheromones in the wool and wax of the rams but not in the urine by smearing wax from around the eyes and bare skin of the flanks of the rams on the nostrils of ewes in a group, applying recently clipped wool over the ewes' muzzle in another group, and spraying urine from the rams on the last group. Ovulation was stimulated in the group of ewes treated with wool and wax relative to those exposed to rams but no significant stimulatory response in ewes treated with rams' urine. These observations were further confirmed by Signoret and Lindsay (1982) and Knight et al. (1983b).

It seems that the pheromones are secreted with the suint as a mixture of oily secretion from the sudoriferous glands and viscous secretion of the odoriferous glands of the skin (Martin et al., 1986). Based on the information presented above, full physical contact with ram is not necessary for induction of a reproductive response but it is required to maximize the response of the ewes to stimuli from rams (Pearce and Oldham, 1988).

There is also a behavioral component of the ram effect. Signoret et al. (1982) reported that castrated males (wethers) with intense sexual activity, which were treated with androgen, induced ovulation more potently than sexually inactive rams treated with the same dosage of androgen. 


\section{Means of overcoming Seasonality in Ewes.}

\section{i. Ram Effect}

As previously noted, ram effect has been the most patent and best known phenomenon among all reproductive effects that are socially mediated in sheep reproduction and still the most investigated based on its considerable economic benefit (Rosa and Bryant, 2002).

An increase in basal LH secretion was documented in a group of ewes within 10 minutes (Martin et al. 1980), and an LH surge within 38 hours of ram introduction during anestrus (Knights et al.,2002) after a pre-conditioning period of isolation from the rams. The exact period of isolation from rams adequate to elicit the ram effect has not been established but varied with each report from as little as 2 weeks to as much as a month, and this also varied with breeds, location and season of the year (Oldham 1980; Martin et al., 1986).

An increase in the frequency of LH pulses due to maintained contact of ewes with rams during anestrous culminated in an LH surge within 54 hours after ram introduction (Chanvallon et al., 2011) and induced synchronized ovulation in anestrous ewes within 40 hours after the LH surge (Oldham et al., 1979; Martin et al., 1986; Scaramuzzi et al., 2014). This first ovulation is referred to as 'silent' ovulation because it is not accompanied by an estrous behavior. In some ewes, silent ovulation usually results in abnormal development of the first corpus luteum followed by regression after 6-7 days. Following premature regression of the CL, the ewes start a new cycle without estrus display but a normal luteal function (Oldham and Martin, 1978). The third wave of ovulation will then be accompanied by estrous behavior around 22- 28 days after ram introduction. Ewes that have normal luteal phase which last for about 10 days after the first 
silent ovulation can exhibit sexual behavior around 17-20 days after initial introduction of rams (Fabre-Nys et al., 2015).

Despite the fact that secretion of LH occurred a few minutes after ram introduction, the presence of the rams with the ewes must be maintained until ovulation so as to achieve a higher percentage of ewes ovulating (Lindsay et al., 1975; Oldman and Cognie, 1980). Signoret et al. (1982) reported that there is reduction in the percentage of ewes that ovulated when the rams were withdrawn within 24 hours. However, some ewes can still return to anoestrus after one or 2 ovulations, in the presence of rams (Rosa and Bryant, 2002).

Continuous exposure of ewes to rams can affect the onset and the end of the breeding season, the duration of oestrus in mature ewes and accelerate the attainment of puberty in ewe lambs (Rosa and Bryant, 2002). According to Donovan et al. (1991), the breeding season ended 3 weeks later and the onset of the next breeding season was earlier by a month in ewes that were continuously exposed to vasectomized rams during the breeding season.

Some breeds of ewes that are less seasonal can be stimulated by rams some months before the onset of the breeding season but if they are introduced to rams in mid-anoestrous season, the ewes can easily return to the anovular condition after the first ovulations (Goodman et al., 1982). This is supported by the findings of Knight (1983) in Australia who observed 22\% and $42 \%$ of Merino ewes exposed to rams in October returned into anoestrus 24 days and 50 days after ram introduction respectively. In breeds of ewes that are more seasonal, where stimulation by rams is only achievable 2 weeks to a month prior to the start of the reproductive season, cyclic activity can be maintained throughout the breeding season (Rosa and Bryant, 2002). 
The effect of ram introduction has also been reported in lactational anoestrous ewes. In a study conducted by Poindron et al. (1980), most of the lactational anoestrous ewes responded with increased LH secretion and ovulation when introduced to the rams 21 days after parturition during breeding season. Also, Wright et al. (1989) discovered that an abrupt ram introduction can bring about oestrus in lactational anoestrous ewes during the breeding season as compared to the ewes that have been in continuous contact with rams for a period of 3 months.

The age and level of experience of the ewes can also play a role in the effectiveness of the ram effect. Ewes that are young in age with no prior sexual experience exhibited lower ovarian response when compared with older ewes with an initial sexual experience (Chanvallon et al., 2010). In pre-pubertal ewes exposed to rams, it was found that there is reduction by 16 days in their mean age at first oestrus and ovulation (Kassem et al., 1989; Al mauly et al., 1991), and reduction by 19 days in the mean age to conception (Kassem et al., 1989).

The effect of rams on induction of ovarian activity might be dependent on sexual performance of the rams. For example, exposure of ewes to rams with high level of sexual performance significantly increased the display of oestrus (95\%) as compared with rams with low level of sexual performance (78\%) (Perkins and Fitzgerald, 1994).

Knights et al. (2002) reported that ram introduction alone can induce increased LH pulse frequency, follicular development, and ovulation in fall-born ewe lambs during seasonal anestrous. Although the use of ram introduction alone to induce fertile estrus in anestrous ewes bred out-of-season has been effective, reproductive responses may be low when compared with ewes that are bred in season (Silva and Ungerfeld, 2006). Therefore, additional treatments along with the ram effect have been used to increase fertility in ewes bred during seasonal anestrous. 


\section{ii. Use of exogenous hormones}

Several studies have been carried out using exogenous hormones to induce fertility in seasonally anestrous ewes. Progesterone for an example has been used as a management tool to effectively synchronize and induce estrus in ewes (Welch et al., 1984; Hamra et al., 1986; Wheaton et al., 1992).

Progesterone can be delivered orally, intravaginally, via implant or injection but intravaginal delivery of progesterone via controlled internal drug releasing devices (CIDRs) is the only approved method for use in the US. Ewes that were pretreated with progesterone via CIDRs displayed estrus behavior earlier and in a more synchronized way when compared with the ewes treated orally with Melengestrol acetate (MGA) (Daniel et al., 2001) or sponges (Welch,1983; Welch et al., 1984). Although, the retention rates of sponges and CIDRs are similar, CIDRs are easily removed while sponges seemed to get stuck to the vaginal constriction (Welch, 1983). The mean concentrations of progesterone produced by the 2 different CIDR types (9\% vs $12 \%$ progesterone), were similar but almost double the mean concentrations produced by the sponges and implants throughout the treatment period in ovariectomized ewes (Hamra et al., 1986).

Three thresholds of progestogen treatment were suggested to be required in stimulating adequate response in the ewes. First threshold is the dose of progestogen necessary for the inhibition of ovulation, followed by a second threshold of higher dose which is required for oestrus and a third with increased dose necessary for optimum fertility (Robinson, 1967; Robinson and Smith, 1967; Robinson et al., 1967).

A rapid and adequate absorption of the progestogen at the initial stage appeared to be necessary for optimum fertility, and this was achieved at the higher doses of progesterone. An increase in 
progesterone dose from 500 to $1000 \mathrm{mg}$ resulted in a linear increase in fertility with similar quantity of progesterone $(250 \mathrm{mg}$ ) absorbed by the ewes regardless of the dose administered within the range of 500-1200 mg (Mac Donnell and Crowley, 1978).

Exogenous hormones can also be used in conjunction with ram effect to achieve an increased fertility in anestrous ewes. Treatment with progesterone $\left(\mathrm{P}_{4}\right)$ just before ram introduction during anestrous period inhibited the untimely regression of corpus luteum in all ewes that ovulated in response to the ram (Pearce et al. 1985) and also increased estrous activity and mating in seasonally anovular ewes at the synchronized ovulation (Jabbar et al., 1994).

Injection of Barbarine ewes with $20 \mathrm{mg}$ of exogenous progesterone at the exact time of ram introduction significantly shortened the number of short estrous cycles and resulted in a more synchronized estrus. Progesterone treatment increased the time from ram introduction to ovulation by about 38- 40 hours causing a delay in the preovulatory surge of LH (Lassoued et al., 1995) and ensuring that only corpora lutea that are responsive to prostaglandin are present in ewes that are undergoing estrous cycles at regular intervals upon withdrawal of progesterone (Acritopoulou and Haresign, 1980). This pretreatment with progesterone facilitates the expression of estrus at the time of the ram-induced ovulation during non-breeding season (Ungerfeld et al., 1999; Knights et al., 2001ab).

In a study to determine the effectiveness of CIDRs (polycapralactone [PCL] insert with $0.82 \mathrm{~g}$ $\mathrm{P}_{4}$ ) to induce fertile estrus and if CIDRs with FSH would increase prolificacy in anestrous ewes introduced to rams, Knights et al. (2000) reported that CIDRs in combination with ram introduction at CIDR removal was more effective than ram introduction alone to induce synchronized estrus and ovulation, yielded higher pregnancy rates after one or 2 service periods. 
Treatment with progesterone (CIDRs) for 5days was also reported to be as effective as for 12 days. Progesterone pretreatment in combination with estrogen and ram introduction also resulted in a high estrous response. Estrous response was greater in ewe lambs treated with estrogen after a $\mathrm{P}_{4}$ pretreatment $(81.8 \%)$ than in ewe lambs that were treated with $\mathrm{P}_{4}$ and introduced to rams alone (45.5\%; Knights et al., 2002).

Co-treatments using gonadotropin is commonly used to successfully establish tight synchrony and provide acceptable level of fertility upon natural mating (Wildeus, 2000). Most of the ewes treated with progestogens and then equine chorionic gonadotropin (eCG) which was formerly referred to as pregnant mare serum gonadotropin (PMSG) displayed estrous behavior but with an average conception rates (Gordon, 1963; Hulet and Foote, 1967; Laster and Glimp, 1974).

Equine chorionic gonadotropin (eCG) acts only like LH in equids but has FSH-like activity in non-equids. According to Lunstra and Christenson (1981), ewes synchronized with progestogen followed by eCG in both in-season and out-of-season breeding showed increased ovulation rate relative to untreated ewes that were bred in season but with marked variability and decreased lambing response. The reduced fertility was suggested to be due to low semen quality or sperm transport of rams, which is attributed to out of season, and possibility of asynchronies of timing of onset of estrus, ovulation and fertilization in the ewes (Lunstra and Christenson, 1981).

Follicular dynamics was also measured in anestrous ewes treated with medroxyprogesterone acetate (MAP) sponges for 12 days after which $750 \mathrm{UI}$ eCG was given at the sponge removal. The MAP and eCG treatments resulted in the recruitment of more ovulatory follicles without any change in the rate of follicular growth, and also increased the size of the ovulatory follicles by delaying ovulation and the LH surge (Leyva et al., 1998). 
In another study by Burfening and Van Horn (1970), pretreatment with 1mg of oestradiol-17 $\beta$ one day prior to a 13-16 day progesterone treatment with eCG at progesterone removal brought an additional $30 \%$ of ewes into oestrus. There was also a $15 \%$ increase in pregnancy to first service in ewes pretreated with estradiol as compare to those without estradiol pretreatment. However, the long-acting biological activity of eCG can result in large number of non-ovulated follicles due to continual recruitment of antra follicles (Armstrong et al., 1983).

The effect of eCG dose on fertility ranging from $250 \mathrm{UI}-750$ UI was investigated in both in season and out of season breeding. It was reported that there is no significant improvement on fertility by increasing the dosage of eCG administered (Ainsworth and Shrestha, 1985; Smith et al., 1988; Knight et al., 1989; Zarkawi et al, 1999, Zeleke et al., 2005). For example, Zaiem et al. (1996) treated ewes during anestrous with 3 doses of eCG (300, 450, $600 \mathrm{IU})$ following 14 day treatment with 40mg of flurogestone acetate (FGA) and reported that the fertility rates for all the 3 doses of eCG were similar $(81.2$ to $84.3 \%)$ but higher $(\mathrm{P}<0.05)$ than ewes in the control group treated with FGA only (57.5\%). There was also increased level of prolificacy at $450 \mathrm{UI}$ (155.5\%) and 600 UI (176.9\%) when compared to those in the control group (130.4\%) which suggested that optimum effect of eCG can be achieved between 450 to 600 IU.

Also, in a review by Baril et al. (1998), it was reported that there is declining fertility in ewes treated with eCG after a prolonged use.

Injection of Merino ewes with $100 \mu \mathrm{g}$ of GnRH 24 hours after the removal of MAP sponge inserted in the ewes for 12 days caused advancement in the time of ovulation during breeding season but showed no effect on the timing of ovulation during anestrous season (Ryan et al., 1992). Also, Jabbour and Evans (1991) reported a reduction in the time to estrus in cyclic Merino 
ewes when they were injected with $100 \mu \mathrm{g}$ of GnRH 12 hours after the removal of MAP sponge inserted in the ewes for 12 days. Injecting GnRH to induce premature ovulations in seasonally anovulatory resulted in high frequency (58\%) of corpora lutea (CL) with a short life span. However the lifespan of CL induced in the ewes injected with $\mathrm{P}_{4}$ alone was normal (Pearce et al., 1985). Therefore, progesterone when used as part of an estrous induction protocol not only facilitate the display of estrus but it has a luteal protection role as well

P.G. $600^{(\mathrm{R})}$ is a product that contains $400 \mathrm{UI}$ and $200 \mathrm{UI}$ of eCG and human chorionic gonadotropin (hCG) per $5 \mathrm{ml}$, respectively and it is approved for use in inducing estrus in pubertal gilt. A few studies have examined its use as part of the protocols for progesterone-based estrus induction system in sheep at the 5ml-dose level prescribed for swine (Wildeus, 2000). In a study conducted by Morrical et al (1995) to evaluate the influence of individual or combined use of MGA and P.G. $600^{(\mathrm{R})}$ on the reproductive performance of ewes out of season, a $20 \%$ increase in conception rate was reported when ewes were injected with $5 \mathrm{ml}$ of P.G. $600^{(\mathrm{R})}$ at 10 days after treatment with MGA. Safranski et al. (1992) however reported that there is no significant effect on conception rate and prolificacy when P.G. $600^{(\mathrm{R})}$ was given after 10 days of MGA treatment but there was increased ovulation rate when compared to MGA treatment only. In another study, Windorski et al. (2009) also reported a level of recruitment, growth and subsequent ovulation of the follicles in anestrous ewes treated with P.G. $600^{(\mathrm{R})}$ and MGA i.e., there was an increased level of recruitment, growth and subsequent ovulation of the follicles when compared with MGA treatment alone but no difference in the ewe prolificacy or fertility between the 2 groups.

More recently, D'Souza et al. (2014) used a lower dose of P.G. $600^{(\mathrm{R})}$ of $3 \mathrm{ml}$ in non-lactating anestrous ewes as estrous induction protocol rather than the $5 \mathrm{ml}$ recommended in swine in an attempt to keep the level of estradiol secreted as the follicles grow from being too high and 
thereby reduce fertility. The authors reported a higher estrous response, conception and pregnancy rates in the treated ewes. Additionally, a similar treatment improved fertility in fallborn ewe lambs bred during mid-anestrous but did not improve fertility in yearling females (Knights et al, 2015). Therefore, the combination of exogenous hormones and "ram effect" can act to improve reproductive performance of seasonally anestrous ewes.

\section{Effect of Lactation on Ewe Fertility}

Several studies reported that lactation increases the interval between parturition and resumption of estrous activity in spring lambing ewes (Pope et al., 1989) and also reduces fertility (Hulet and Foote, 1967). Further, lactating ewes tend to resume reproductive activity later than ewes that have their lambs weaned off earlier after lambing (Mallampati et al. 1971, Restall, 1971, Sefidbakht et al., 1971).

A slow increase in the LH levels was reported after lambing and this is indicative of a gradual physiological recovery of the pituitary (Restall and Starr, 1977) but suckling prevents the secretion of LH at early postpartum (Stellflug et al., 2001) via the secretion of endogenous opioids (Lozano et al., 1998) that are partially responsible for the negative feedback of estradiol on GnRH-LH pathway (McNeilly, 1994). There is an increase in the frequency and the duration of suckling as the lambs grow older with a 3 fold increase in suckling intensity of lambs that were unrestricted to suckle compared to those that were restricted to 3 times daily (Mandiki et al., 1990) which may be the reason for suppression of ovulation in ewes that have lactated longer.

In a study carried out in Winter and Spring lambing ewes, Restall and Starr (1977) reported that more ewes ovulated from the group of ewes that had their lambs removed at birth (72\%) than in 
group of ewes that were lactating for 40 days postpartum (40\%) with more elevations of $\mathrm{LH}$ levels in the former (64\%) than the latter (43.8\%). Also in an experiment carried out by Pevsner et al. (2010), the presence of lambs were reported to be a depressing factor of both ovulation and estrous responses to the ram effect in lactating ewes in the spring and removing lambs from the ewes for 24 hours before stimulation may increase ovulation response.

In lactating ewes, uterine involution can be a limitation aside from the interval between parturition and resumption of cyclicity. When fall lambing ewes are maintained at high nutritional plane, uterine involution is completed by third week after lambing (Rubianes and Ungerfeld, 1993) and according to Rubianes et al. (1996), the first oestrus is seen in the ewes around 50days postpartum. In a study conducted on 50 ewes that lactated for 1, 24 and 56 days, Shevah et al. (1974) reported that 8 out of 17 ewes that suckled for 1 day displayed spontaneous oestrus 2 - 20days postpartum compared to only one out of the 33 that lactated for 24 and 56 days. All the ewes displayed estrus behavior after 12days treatment with progestagen vaginal sponges beginning from 20-24 days postpartum. The mean intervals between sponge removal and onset of estrus for ewes that were suckled lambs for 1, 24 and 56 days were $35.3 \pm 1.5,33.2$ \pm 1.6 and $41.0 \pm 1.5$ hours respectively $(\mathrm{P}<0.01)$

Nearly all the lactating ewes that were treated from 3 days after lambing with various combinations of progestogen (MAP) and eCG ovulated before 15 days postpartum irrespective of the season of lambing with certain proportion (29\%) showing oestrus after further treatment with MAP and eCG between days 15-26 postpartum (Restall et al., 1978). The authors further reported low fertility $(17 \%)$ in spring lambing crossbred ewes when mating was induced up to 30days postpartum which improved in later mating, (30\%). 
Another major limitation to oestrus and ovarian resumption after parturition is the body weight loss (Mbayahaga et al., 1998) which may be suckling-induced. Haresign (1981) reported that under-nutrition resulted in reduction in body condition of ewes, reduction in the LH pulse frequency and consequently the reproductive performance of ewes.

In a study to evaluate the effect of different levels of body condition on reproductive performance of North Country Cheviot ewes, Gunn et al. (1991) reported a lower ovulation rate in ewes with low body condition scores of less or equal to 2.5 at 5 weeks prior to mating but a significant increase in ovulation, conception and lambing rates was observed in ewes with higher body condition scores. According to Molina et al. (1994), the body condition score at mating affected the fertility of the Manchega ewes $(\mathrm{P}<0.05)$ with fertility rate exceeding $80 \%$ in the ewes with high body condition score even in the least fertile mating season (spring- summer months).

Weaning may be a useful tool in improving reproductive performance in postpartum ewes. (Ungerfeld and Sanchez-Davila, 2012). The combination of hormonal treatment with weaning at 7 or 40days after parturition, or restricted suckling improves reproductive efficiency in Pelibuey ewes (Ronquillo et al., 2008). However, in some other studies, weaning has been reported to be unbeneficial (Warren et al., 1989; deNicolo et al., 2006) to the reproductive responses of ewes treated with exogenous hormones.

Ungerfeld and Sanchez-Davila (2012) evaluated the effect of lamb weaning on the response of postpartum ewes to oestrus synchronization or induction treatments during breeding season and reported that there is possibility of inducing fertile oestrus in lactating ewes during early postpartum and that weaning lambs early before stimulation did not improve the response of the 
ewes. This was also supported by the experiment carried out by Pope et al. (1989) who recorded that ewes that suckled for 40 days during the spring had higher conception rates than ewes whose lambs were weaned at birth. A beneficial effect of lactation was reported by Hashem et al. (2011) as higher number of follicles was recorded in lactating ewes than in dry ewes during nonbreeding season. This may be responsible for an increased ovulation rate, pregnancy rate and litter size in ewes bred while lactating (Pope et al., 1989; Forgarty et al., 1992).

Hashem et al. (2011) concluded that the reduction in estrus behavior was mainly due to seasonal effect rather than lactational stress. The authors reported that incidence of estrus, which was significantly affected by the season, was higher in ewes that lambed during the breeding season than those that lambed during non-breeding season. Highest proportion of estrus rate and lowest postpartum anestrus interval were achieved during the first lactation stage which represents the highest lactational strength (40-60 days) in ewes that lambed earlier in the breeding season (August, September and October) than later in the breeding season (November and December).

\section{Effect of Weaning on Lamb Growth and Survival}

Total profitability in sheep enterprises is basically evaluated by sheep productivity and high productivity is achieved through optimization of reproduction in ewes, as well as lamb growth and survival (Boujenane et al., 1998). While weaning is often used to enhance early rebreeding of ewes in accelerated lambing programs and early resumption of cyclicity in lactating ewes by suppressing the effect of suckling and reducing the nutrient demand on the ewe, it involves physical separation of the dam and lamb and modification to the feeding habit of the lambs, both of which can induce stress in both the mother and the young (Orgeur et al., 1998). 
Stress, such as the separation of mother and young causes the activation of the hypothalamicpituitary-adrenal system and the autonomic nervous system so as to make necessary adjustment in response to the social perturbation (Mormede, 1995). Stress can have a deleterious effect on animal health and welfare by inducing a malfunctioning of the immune system. In a study to measure the consequences of 2 weaning protocols; progressive weaning- daily separation which increased in duration starting when lambs are 3.5 weeks old till definitive weaning at 3 months, and sudden weaning- weaning abruptly at 3 months, Orgeur et al (1998) reported that none of the procedures seemed highly stressful in sheep, with the most striking difference been the vocalizations of the animals which was suppressed after 2 days in sudden weaning as compared to its persistence throughout all the periods of temporary separation in progressive weaning. Lambs showed higher level of sensitivity to parasite infestation in the progressive weaning procedure which may be explained to be as a result of greater sensitivity to parasite at a younger age. This may also be due to compromised immune system consequential to stress from repetitive daily dam-lamb separation until weaning in the progressive weaning procedure (Karakus, 2014).

Watson and Gill (1991) reported that lambs suckled for 3 months have much better prospects than weaned lambs when faced with a substantial parasite challenge. In a study carried out by these authors, the mean fecal egg count for weaned lambs at 12 weeks was twice that for controls when lambs were experimentally infected with 5,000 haemonchus contortus and 10,000 Trichostrongylus colubriformis larvae at 8 weeks. This was attributed to the possibility of a better immune response in the suckled lambs as a result of milk feeding. In another study, Iposu (2007) concluded that suckling may lower the establishment of nematode larvae through direct effect of 
milk and also enhance development of host immunity to infection. This was further supported by Zeng et al. (2001) who established that worm burdens were lower in milk-fed lambs.

In a study conducted by Vecihi et al. (2009) to investigate the effect of 45, 60 and 75 days of weaning on growth and survival rates in Awassi lambs, it was reported that survival rate was significantly lower in the group of lambs weaned at 45 days old when calculated on days 120 and 210 compared to the other 2 groups, and also the live weight gain was lower in lambs weaned at 45 days when calculated on day 210. According to Knights et al., (2012) higher levels of mortality observed in lambs that were weaned early may be partly due to reduced immune function.

High growth rate in lambs is dependent on an adequate supply of milk and availability of high quality forage (Geenty and Sykes, 1983). Dikmen et al. (2007) reported that there is a tendency for a higher live weight in lambs kept on their mother to suckle for the first 60 days of lactation compared to those kept on their mother for only 9 hours daily from 3 days postpartum. Early weaning between $7-8$ weeks caused about $25 \%$ reduction in the live-weight gain of the lambs compared to weaning at 14-16 weeks which grew 30\% faster (Dynes et al., 2006). Lambs that were weaned early showed a continuous reduction in their growth rate which persists for the duration of about 2 months while an increased growth rate has been reported in lambs that were suckled continuously or un-weaned as compared to lambs weaned early (Simpson-Rastle et al.,2012; Knights et al., 2012). 


\section{PROBLEM STATEMENT}

Increasing the frequency of lambing can increase lifetime productivity of the ewe and profitability of sheep operations. However, the seasonality of reproduction in sheep limits lambing to once per year which contributes to the low productivity of the ewe in traditional production systems. Attempts to increase the frequency of lambing by inducing fertile estrus in dry anestrous ewes with use of progesterone pre-treatment prior to ram introduction have been attempted (Knights et al., 2001ab; D'Souza et al., 2014). These approaches capitalize on the raminduced secretion of gonadotropins and ovulation, the "ram-effect". However, early weaning of lambs have resulted in reduced growth and productivity of the weaned lambs (Schichowski et al., 2010; Knights et al., 2011; Simpson-Rastle et al.,2012; Karakus, 2014;), which negatively impacts any gains in productivity earned through increase frequency of lambing.

While early re-breeding of lactating ewes is desirable and can be achieved in ewes that lamb in the fall, attempts to rebreed lactating ewes during the non-breeding season has not been successful. Suckling has been known to reduce secretion of gonadotropin and might impact the ram-induced release of these hormones. Whether the poor reproductive response of lactating ewes during anestrus is due to a failure of rams to induce the ram effect response, and whether reproductive outcome can be improved by providing exogenous gonadotropins have not been fully evaluated.

Loss of body weight (lower body condition) irrespective of the season is associated with lactation due to the nutrient demand placed on the ewe by the suckling lambs. Loss of body weight and low body condition score are also known to suppress LH pulse frequency and 
reproductive performance. The effect of nutritional supplementation on its own and in combination with gonadotropin supplementation is yet to be fully evaluated.

Tropical hair sheep breeds are capable of breeding year round under tropical conditions and are less seasonal in temperate regions. The Katahdin breed of sheep was developed with the inclusion of tropical hair sheep genetics. However, little data exist on the ability of this breed to conceive during the anestrous period and in particular while lactating.

Therefore, the overall objective of this study was to evaluate the effect of lactation status, and gonadotropin and nutritional supplementation on the induction of LH surge and subsequent fertility on early rebreeding of Katahdin ewes during the seasonal anestrous period. 


\section{INTRODUCTION}

Increasing the frequency of lambing using accelerated lambing programs holds great potential for increasing the productivity and profitability of sheep operations. Accelerated lambing programs often involve rebreeding of ewes by 3 months after lambing so as to achieve a lambing interval of 8 instead of 12 months. To rebreed ewes in the early postpartum period, lambs are typically weaned from the dams as part of the management strategy (Pevsner et al., 2010). However, lambs separated from their dams before 3 months of age may be more susceptible to diseases due to underdeveloped immune system and may experience stress which results in reduced feed intake and growth rate (Karakus, 2014; Dwyer, 2008; Schichowski et al., 2010; Knights et al., 2011). Therefore, developing reproductive management strategies to successfully rebreed ewes while they are still suckling their lambs would increase the frequency of lambing without compromising growth and health of lambs.

The abrupt introduction of rams during anestrus induces the "ram effect" response, which is characterized by increased secretion of the gonadotropins, follicle growth and ovulation in dry (non-lactating) ewes. The ram effect can also induce fertile estrus if ewes are pretreated with progesterone only (Knights et al., 2001ab). Further, small improvements in reproductive outcome in dry mature (D’Souza et al., 2014) and nulliparous (Knights et al., 2015) ewes bred during anestrus have been achieved by providing exogenous gonadotropins at the time of progesterone withdrawal and ram introduction. The reproductive outcomes following attempts to rebreed lactating ewes during seasonal anestrus have largely been unsuccessful (Whiteman et al., 1972; Mandiki et al., 1990; Cognie et al., 1975; Silva and Ungerfeld, 2006; Martemucci and 
D'Alessandro, 2010). Whether the poor reproductive performance in lactating ewes bred during seasonal anestrus is due to a muted "ram effect" response and whether supplementation with gonadotropins can improve reproductive outcome in lactating ewes have not been fully investigated.

Significant loss of body weight of ewes can occur during lactation, and loss in body weight can delay the resumption of estrous cycles and early rebreeding of females (Mbayahaga et al., 1988). Feed supplementation can be used to minimize the loss in body weight during lactation. Ewes maintained on a higher plane of nutrition had a shorter duration of anestrus and resumed ovarian activity earlier compared to those maintained on a lower plane of nutrition (Menassol et al., 2012). The effect of feed supplementation on the "ram-effect" response and fertility of lactating ewes bred during anestrus has not been fully established.

Therefore, the objectives of this study were: 1. To evaluate the effect of progesterone gonadotropin supplementation and lactation status on the ram-induced LH surge. 2. To evaluate the specific effect of gonadotropin supplementation and lactation on the ram-induced LH surge, and fertility. 3. To compare the independent and combined effects of gonadotropin and nutritional supplementation on the ram-induced LH surge and fertility in lactating ewes. 


\section{MATERIALS AND METHODS}

\section{Location and Animals}

This study was carried out at the West Virginia University Farm in Wardensville, WV located at $39.10^{\circ} \mathrm{N}, 78.58^{\circ} \mathrm{W}$, using mature Katahdin ewes during Summer (June) of 2014 and 2015. Rams and ewes were separated for at least a month prior to the start of the experiment. Rams were introduced to the ewes in a confined pasture to ensure proper stimulation at a ram to ewe ratio of not less than of 1:9. The rams were joined with the ewes for about 40 days into the experiment starting from the day of controlled internal drug releasing device (CIDR, containing $300 \mathrm{mg}$ of progesterone; InterAg; Hamilton, New Zealand) removal.

\section{Experimental Approach}

All procedures were approved by the West Virginia University Animal Care and Use Committee (PROTOCOL \# 14-0604).

\section{Experiment 1}

A $2 \times 2$ factorial arrangement of treatments was used to evaluate the effects of an estrus induction protocol and lactation status on the ability of rams to induce an LH surge in ewes during the anestrous period. Ewes $(\mathrm{N}=32)$ that were either separated from their lambs at least 3 months earlier and were non-lactating/dry ( $\mathrm{n}=16$; DRY) or were being suckled by their lambs (lactating; $\mathrm{n}=16$; LACT) were randomly assigned to receive the estrus induction protocol (EIP) or no further treatment $(\mathrm{CON})$. The estrus induction protocol was previously shown to be effective in getting dry ewes to breed out-of-season (D’Souza et al., 2014; Knights et al., 2015) and consisted of a 5 day pre-treatment with progesterone delivered by a controlled internal drug releasing device (CIDR, 0.3 g progesterone; InterAg; Hamilton, New Zealand) and gonadotropin stimulation (GS) using a single injection of a gonadotropin mixture PG 600 (3 mls i.m., 240 IU 
PMSG + $120 \mathrm{IU}$ hCG). Ewes in the four treatment groups (DRYEIP, DRYCON, LACTEIP and LACTCON, $\mathrm{n}=8$ each) were introduced to rams with marking harnesses when progesterone/CIDRs were removed from the EIP treated ewes.

\section{Experiment 2}

Experiment 2 was similar to experiment 1 and was designed to evaluate the effects of lactation status and gonadotropin supplementation on the ram-induced LH surge and subsequent fertility. Briefly, lactating (LACT; $\mathrm{n}=58$; approximately $68.7 \pm 1.3$ days postpartum) and dry ewes (DRY; $\mathrm{n}=22$ ) were treated with CIDR devices for 5 days. On the day of insert removal, ewes in each lactation status were randomly selected to receive GS (DRYGS; $\mathrm{n}=11$, LACTGS; $\mathrm{n}=31$ ) or no further treatment (DRYCON; $\mathrm{n}=11, \mathrm{LACTCON} ; \mathrm{n}=27$ ). Lactating ewes were balanced for birth type. All ewes were then exposed to rams. Blood samples were collected from a subset of ewes $(\mathrm{N}=33)$ for analysis of the $\mathrm{LH}$ profile and pregnancy diagnosis was conducted on all ewes by ultrasonography 30 days later.

\section{Experiment 3}

In experiment 3, the effects of level of nutritional supplementation and GS on ability of rams to induce an LH surge and on the subsequent fertility of ewes during the anestrous period was evaluated. At approximately $38 \pm 1.3$ days postpartum ewes $(\mathrm{N}=87)$ were randomly assigned within rearing type to be given a high or low level of grain supplementation for 30 days (HIGH; $1.14 \mathrm{~kg}$ and LOW; $0.68 \mathrm{~kg}$, of a $13.3 \%$ crude protein $(\mathrm{CP})$ ration; equivalent to $50 \%$ and $30 \% \mathrm{CP}$ respectively). At the end of the 30 day supplementation period all ewes were treated with CIDR devices for 5 days and half of the ewes assigned to each grain supplementation level were randomly assigned to receive GS or no further treatment prior to exposure to rams. Blood 
samples were collected from a subset of ewes $(\mathrm{N}=22)$ for analysis of the LH profile and pregnancy diagnosis were conducted on all ewes as described in experiment 2.

\section{Estrus Detection}

Rams were fitted with marking harnesses when introduced to the ewes so as to monitor sexual activity. The occurrence of estrus was determined by observation of ewes for raddle marks from day 0- 4 after the introduction of ram.

\section{Blood Collection and LH Quantification}

Blood samples were taken via jugular venipuncture. In the first experiment, blood samples were taken every 4 hours for 40 hours beginning at ram introduction $(0 \mathrm{~h})$. In experiments 2 and 3 blood samples were taken $2 \mathrm{~h}$ prior to ram introduction $(-2 \mathrm{~h})$, at ram introduction $(0 \mathrm{~h})$ and at 2 , $4,6,12,16,20,24,28,32,36,40,44,48$ hours after ram introduction. All blood samples were collected into heparinized tubes (EDTA; Monoject, 15\% EDTA K3 liquid, Tyco Healthcare Group, Mansfield, Massachusetts, USA) and centrifuged for 20 minutes at 3000 rotations per minute. Plasma was harvested and kept frozen at $-20^{\circ} \mathrm{C}$ until used for quantification of LH. Using a radioimmunoassay that has previously been validated in sheep (Goodman et al., 2004), LH was measured in duplicate using $100 \mu \mathrm{l}$ of plasma and expressed in terms of NIH-LH-S12. The minimal detectable concentration of LH in these assays averaged $0.10 \mathrm{ng} /$ tube; intra- and inter-assay coefficients of variation were $15.0 \%$ and $18.2 \%$, respectively. 


\section{Pregnancy Diagnosis}

The ewes were examined via trans-rectal ultrasonography using an Aloka 500 (Corometrics medical Systems, Wallingford, CT, USA) with a 7.5MHz linear trans-rectal probe, 30 - 35days after ram introduction to determine pregnancy to the first service period.

\section{Statistical analysis}

An analysis of variance (ANOVA) was conducted using the GLM procedure of SAS (Statistical Analysis System version 9.4 for Windows; SAS Institute, Cary, NC, USA) with fixed effects of lactation status (LS) and EIP (Experiment 1), LS and GS (Experiment 2), level of grain supplementation and GS (Experiment 3) and their interactions. Response variables included proportion of animals with a detectable LH surge, time to peak of the LH surge (hours from introduction of rams to the highest LH values in animals in which an LH surge was detected), and peak concentration of LH (highest LH values in animals in which an LH surge was detected). Chi-square analysis using the PROC FREQ procedure of SAS was used to evaluate the following response variables; proportion of ewes with a detectable LH surge, proportion of ewes detected in estrus; proportion of ewes in which an LH surge (the first sample in which concentration of LH exceeded the base line after introduction of rams ; mean of first 2 samples, by two standard deviations) was detected, pregnancy and conception rates to the first service period (number of ewes pregnant at pregnancy diagnosis as a percentage all ewes exposed to rams and of ewes detected in estrus, respectively). When appropriate, Fisher's exact test of independence was used. Least square means were calculated for all variables and differences were considered significant at $\mathrm{P} \leq 0.05$ and tending to be different at $0.05<\mathrm{P} \leq 0.1$. 


\section{RESULTS}

\section{Experiment 1}

In experiment 1 , the proportion of ewes with a detectable $\mathrm{LH}$ surge was greater $(\mathrm{P}=0.0001$; 93.75\% vs. $18.75 \%$; figure 2) in ewes receiving the EIP than in ewes exposed to rams only, but was not affected by lactation status. In animals with a detectable LH surge, the mean peak concentration of $\mathrm{LH}$ and time to peak concentration $(68.1 \pm 25.5 \mathrm{ng} / \mathrm{ml}$ and $35.5 \pm 2.7 \mathrm{~h}$, respectively) was not affected by lactation status, the use of an EIP or their interaction.

\section{Experiment 2}

In Experiment 2 the mean proportion of ewes with a detectable $\mathrm{LH}$ surge was $72.7 \%$ and tended to be significantly higher in ewes receiving $(87.1 \%)$ than in ewes not receiving gonadotropin stimulation $(57.2 \% ; \mathrm{P}=0.07$; Table 1 ; figure 3$)$. There was no effect of treatments on the peak or time to peak concentration of LH in ewes with a detectable LH surge (Table 1).

The estrous response was not affected by lactation status but was higher in ewes receiving (63.9 \pm 8.7) than in ewes not receiving gonadotropin stimulation $(38.6 \pm 8.7 ; \mathrm{P}=0.0450$; Table 1 ; figure 4). Gonadotropin stimulation tended to increase estrous response in lactating but not in dry ewes (LACT X GS, P =0.1; figure 4). Conception and pregnancy rates were lower in lactating than in dry ewes ( $\mathrm{P}=0.0172,0.0131$, respectively) but were not affected by gonadotropin stimulation (figures 5 and 6, respectively). 


\section{Experiment 3}

Experiment 3 was conducted with only lactating ewes. The proportion of ewes with a detectable LH surge was not affected by level of nutritional supplementation but tended to be higher in ewes receiving than in ewes not receiving gonadotropin stimulation $(\mathrm{P}=0.06 ; 91.7 \pm 31$ vs $55 \pm$ 13\%; Table 2; figure 7). In ewes with a detectable LH surge, neither the peak concentration nor the time to peak LH concentration was affected by treatments (Table 2). The pattern of LH secretion in ewes with a detectable LH surge and ewes in which an LH surge was not detected is shown in figures $8(a, b, c)$ and $8(d, e)$, respectively. Figures $9(a, b)$ show the pattern of LH secretion of ewes that were detected in estrus and diagnosed pregnant but without a detectable LH surge.

The estrous response was higher in ewes receiving than in ewes not receiving gonadotropin stimulation $(\mathrm{P}=0.009)$ and tended to be higher $(\mathrm{P}=0.1)$ in ewes on the high compared to the low level of nutritional supplementation (figure 10). There was no effect of treatments on conception rate, however, the pregnancy rate was higher in ewes receiving the high compared to the low level of supplementation $(\mathrm{P}=0.05)$ and in ewes receiving compared to those not receiving gonadotropin stimulation $(\mathrm{P}=0.003$; figure 11). 
Table 1 (Experiment 2): Effect of Lactation and Gonadotropin Stimulation on Characteristics of the Ram-Induced LH Surge and Pregnancy; Means \pm SEM.

\begin{tabular}{|c|c|c|c|c|c|c|c|c|c|}
\hline & & Lactating & & & Dry & & & P-Value & \\
\hline $\begin{array}{l}\text { Variabl } \\
\text { e }\end{array}$ & $\begin{array}{c}\text { Gonadotropin } \\
+\end{array}$ & $\begin{array}{c}\text { Gonadotropin } \\
-\end{array}$ & Mean & $\begin{array}{c}\text { Gonadotropin } \\
+\end{array}$ & $\begin{array}{c}\text { Gonadotropin } \\
-\end{array}$ & Mean & $\begin{array}{l}\text { Lactation } \\
\text { (L) }\end{array}$ & $\begin{array}{c}\text { Gonadotropin } \\
\text { (G) }\end{array}$ & $\begin{array}{l}\text { Interaction } \\
\quad(L \times G)\end{array}$ \\
\hline$N(*)$ & $31(6)$ & $27(5)$ & $58(11)$ & $11(11)$ & $11(11)$ & 22 & - & - & - \\
\hline LH Surge (\%) & $83.3 \pm 18$ & $60 \pm 20$ & $71.7 \pm 13$ & $90.9 \pm 13$ & $54.5 \pm 13.3$ & $72.7 \pm 9$ & NS & 0.07 & NS \\
\hline $\begin{array}{l}\text { LH Surge Peak Time } \\
\text { (h) }\end{array}$ & $38.4 \pm 7.7$ & $40 \pm 6$ & $39.2 \pm 3.8$ & $34.4 \pm 3.3$ & $38.7 \pm 4.3$ & $36.5 \pm 2.7$ & NS & NS & NS \\
\hline $\begin{array}{l}\text { LH Surge Peak Conc. } \\
\text { (ng/ml) }\end{array}$ & $97.4 \pm 26$ & $95.4 \pm 34$ & $96.4 \pm 21$ & $82.2 \pm 18$ & $93.9 \pm 24$ & $88 \pm 15$ & NS & NS & NS \\
\hline Estrus & $67.9 \pm 9$ & $22.2 \pm 10$ & $45.3 \pm 7$ & $60.0 \pm 15.0$ & $54.5 \pm 14.3$ & $57.3 \pm 10$ & NS & 0.0450 & 0.1 \\
\hline Conception rate $(\%)^{\mathbf{a}}$ & $57.9 \pm 9.6$ & $60 \pm 19$ & $58.9 \pm 10$ & $100 \pm 18$ & $100 \pm 18$ & $100 \pm 12$ & 0.0172 & NS & NS \\
\hline Pregnancy rate $(\%)^{b}$ & $39.3 \pm 9$ & $13.6 \pm 10$ & $26.5 \pm 7$ & $60.0 \pm 14.4$ & $54.5 \pm 13.8$ & $57.3 \pm 10$ & 0.0131 & NS & NS \\
\hline
\end{tabular}

(*) Number in parenthesis represents the number of animals that were bled for determination of LH concentration.

a Number of ewes diagnosed as pregnant on day 30 as a percentage of the ewes that were observed to be in estrus

b Number of ewes diagnosed pregnant on day 30 as a percentage of all ewes exposed to rams 
Table 2 (Experiment 3): Effect of Level of Supplementation and Gonadotropin Stimulation on Characteristics of the Ram-Induced LH Surge and Pregnancy; Means \pm SEM.

\begin{tabular}{|c|c|c|c|c|c|c|c|c|c|}
\hline & \multicolumn{3}{|c|}{ Low Supplement } & \multicolumn{3}{|c|}{ High Supplement } & \multicolumn{3}{|c|}{ P-Value } \\
\hline Variable & $\begin{array}{c}\text { Gonadotropin } \\
+\end{array}$ & $\begin{array}{c}\text { Gonadotropin } \\
-\end{array}$ & Mean & $\begin{array}{c}\text { Gonadotropin } \\
+\end{array}$ & $\begin{array}{c}\text { Gonadotropin } \\
-\end{array}$ & Mean & $\begin{array}{l}\text { Supplement } \\
\text { (S) }\end{array}$ & $\begin{array}{c}\text { Gonadotropi } \\
\mathbf{n} \\
\text { (G) }\end{array}$ & $\begin{array}{l}\text { Interactio } \\
\text { n (S X G) }\end{array}$ \\
\hline $\begin{array}{l}\mathbf{N} \\
(*)\end{array}$ & $28(6)$ & $22(5)$ & $50(11)$ & $18(5)$ & $19(6)$ & $37(11)$ & - & - & - \\
\hline LH Surge (\%) & $83.3 \pm 18$ & $50 \pm 18$ & $71.7 \pm 13$ & $100 \pm 18$ & $60.0 \pm 20$ & $75 \pm 13$ & NS & 0.06 & NS \\
\hline $\begin{array}{l}\text { LH Surge Peak Time } \\
\text { (h) }\end{array}$ & $38.4 \pm 2.6$ & $40 \pm 3.3$ & $39.2 \pm 2.1$ & $34.4 \pm 2.6$ & $38.7 \pm 3.3$ & $36.5 \pm 2.1$ & NS & NS & NS \\
\hline $\begin{array}{l}\text { LH Surge Peak Conc. } \\
(\mathrm{ng} / \mathrm{ml})\end{array}$ & $97.4 \pm 25$ & $95.4 \pm 33$ & $96 \pm 21$ & $101 \pm 25$ & $64.7 \pm 33$ & $83 \pm 21$ & NS & NS & NS \\
\hline Days Postpartum & $65.9 \pm 2.3$ & $69.5 \pm 2.6$ & $67.7 \pm 1.7$ & $70.5 \pm 3$ & $70.1 \pm 2.8$ & $70.3 \pm 2$ & NS & NS & NS \\
\hline Estrus & $62.5 \pm 8.3$ & $22.2 \pm 9.1$ & $42.4 \pm 6.2$ & $72.2 \pm 11.1$ & $45.0 \pm 10.6$ & $58.6 \pm 7.7$ & 0.1 & 0.0009 & NS \\
\hline Conception rate (\%) & $55 \pm 11$ & $66.7 \pm 20$ & $60.8 \pm 11$ & $83.3 \pm 14$ & $55.5 \pm 16$ & $69.4 \pm 11$ & NS & NS & NS \\
\hline Pregnancy rate (\%) & $35.5 \pm 8$ & $14.8 \pm 8.6$ & $25.1 \pm 5.9$ & $62.5 \pm 11.2$ & $25 \pm 10$ & $43.8 \pm 7.5$ & 0.05 & 0.003 & NS \\
\hline
\end{tabular}

(*) Number in parenthesis represents the number of animals that were bled for determination of LH concentration.

a Number of ewes diagnosed as pregnant on day 30 as a percentage of the ewes that were observed to be in estrus

b Number of ewes diagnosed pregnant on day 30 as a percentage of all ewes exposed to rams 


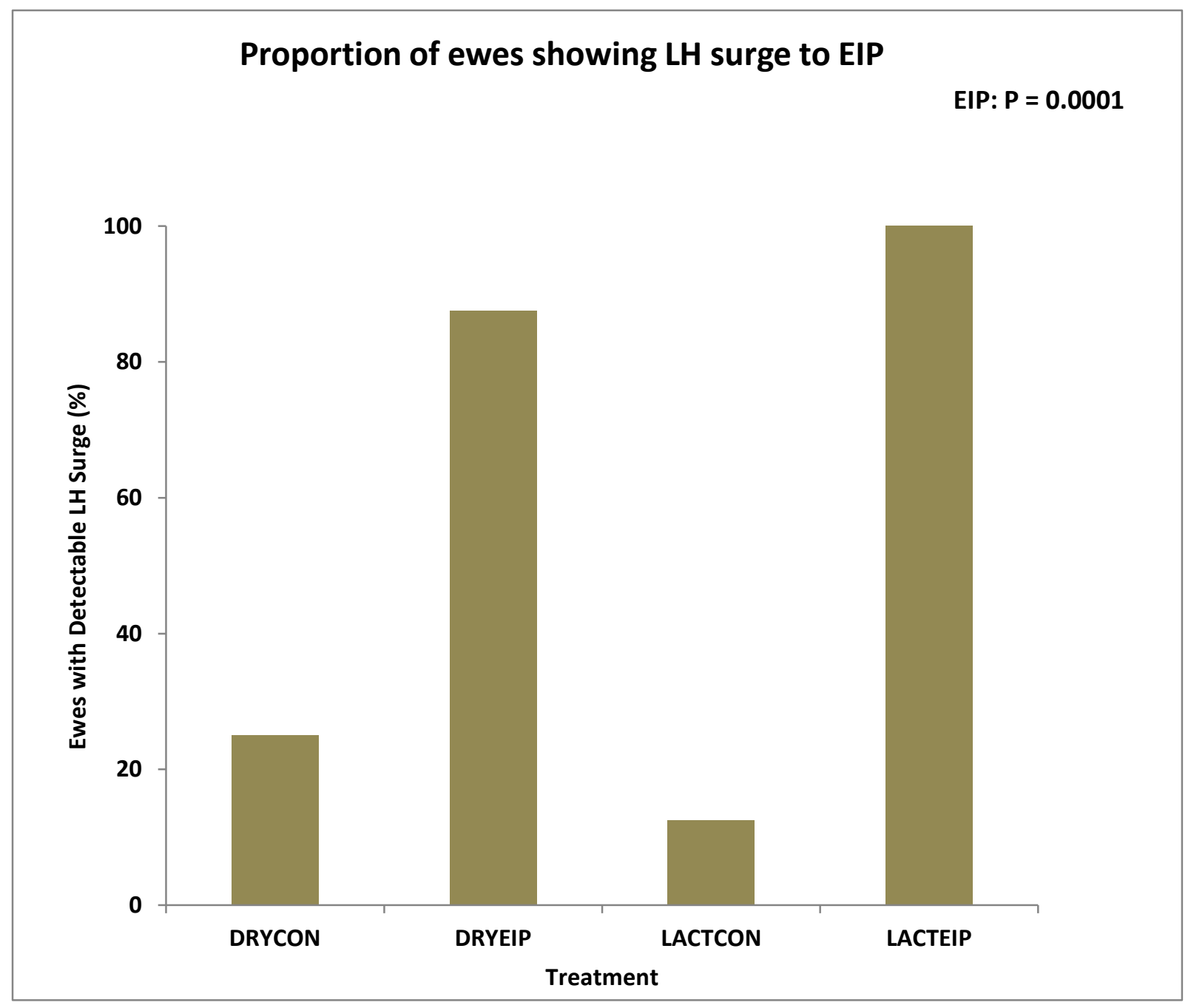

Figure 2. The proportion of dry (DRY) and lactating (LACT) ewes treated with (EIP) or without (CON) an estrus induction protocol during anestrus showing a LH surge (Experiment 1). LH surge was calculated as the first sample in which concentration of LH exceeded the baseline (mean of first 2 samples) by 2 standard deviations. 


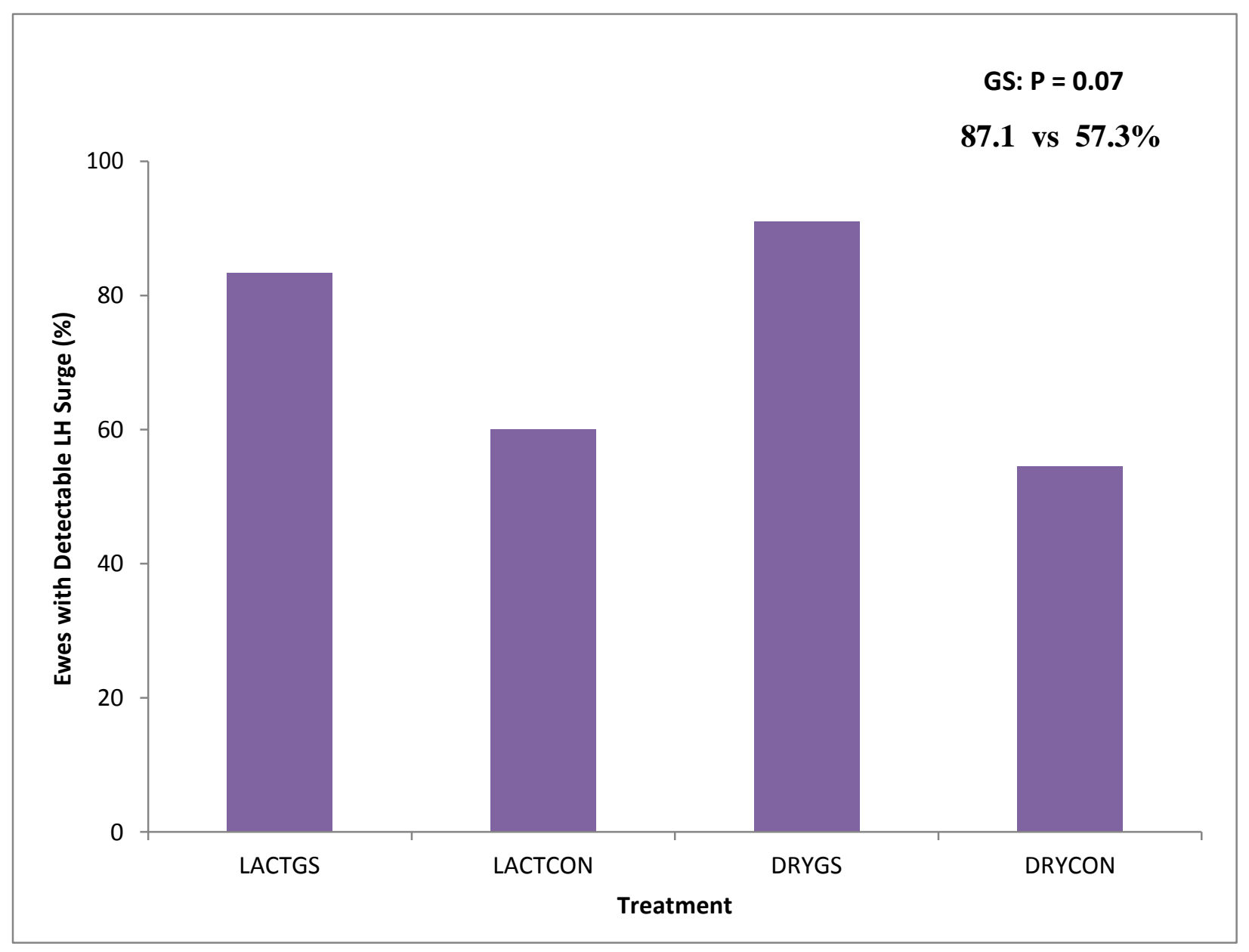

Figure 3. The proportion of dry (DRY) and lactating (LACT) ewes treated with (GS) or without (CON) a gonadotropin mixture following a 5-day progesterone pre-treatment during anestrus showing a LH surge (Experiment 2). LH surge was calculated as the first sample in which concentration of LH exceeded the baseline (mean of first 2 samples) by 2 standard deviations. 


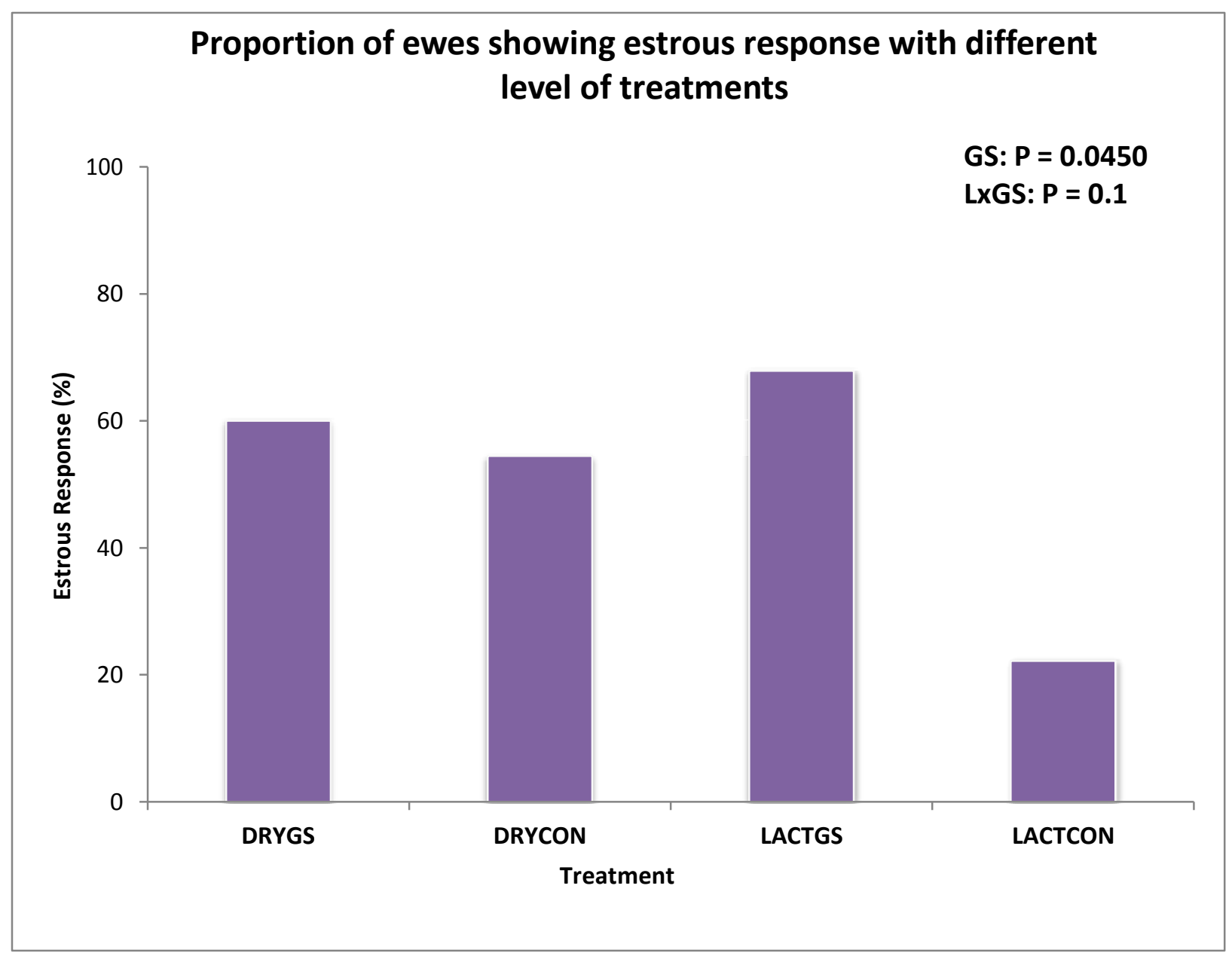

Figure 4. Estrous response in dry (DRY) and lactating (LACT) ewes treated with (GS) or without (CON) a gonadotropin mixture following a 5-day progesterone pre-treatment during anestrus (Experiment 2). 


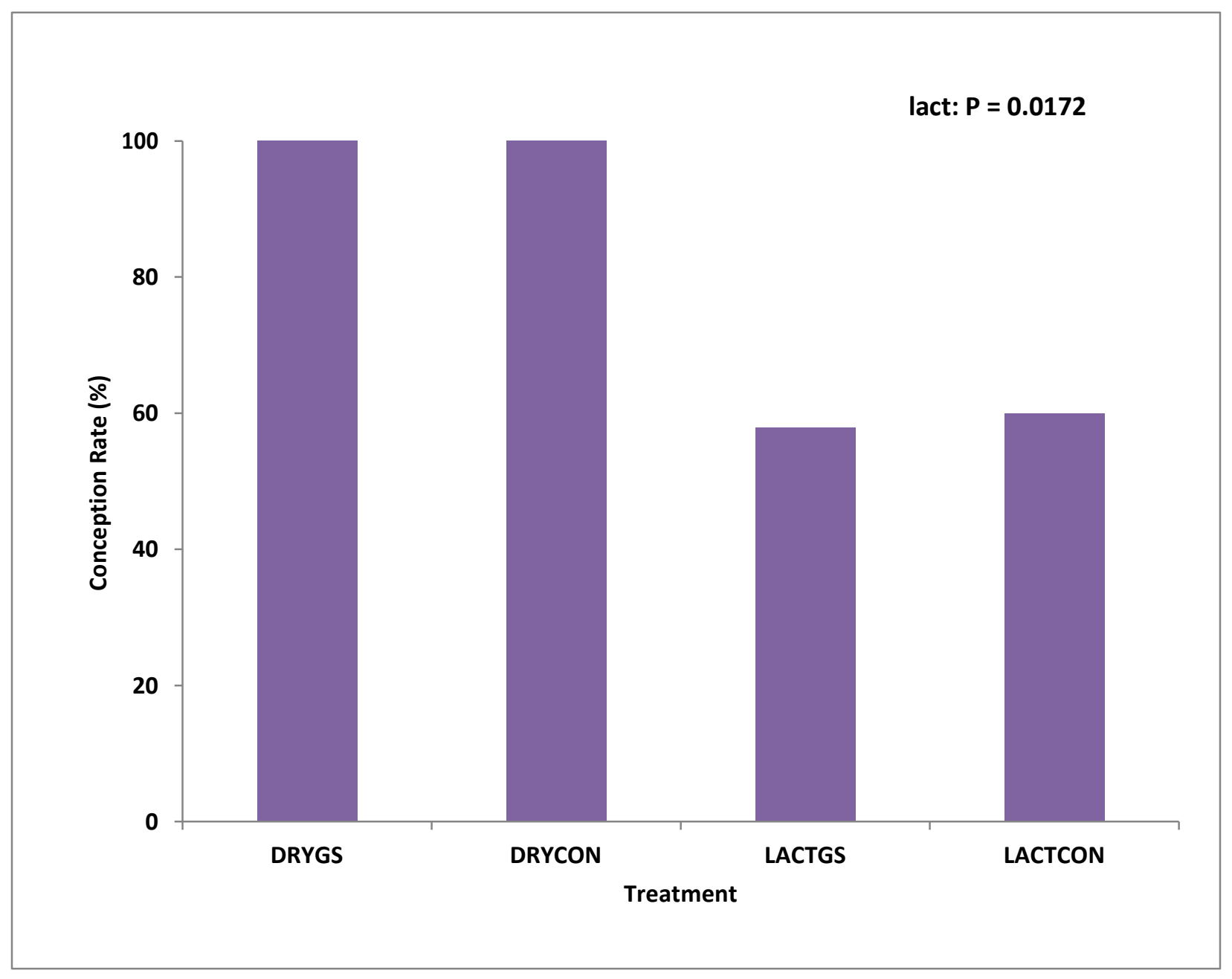

Figure 5. Conception rate in dry (DRY) and lactating (LACT) ewes treated with (GS) or without (CON) a gonadotropin mixture following a 5-day progesterone pre-treatment during anestrus. Conception rate was calculated as the proportion of ewes diagnosed to be pregnant of the ewes observed in estrus following introduction of ram (Experiment 2). 


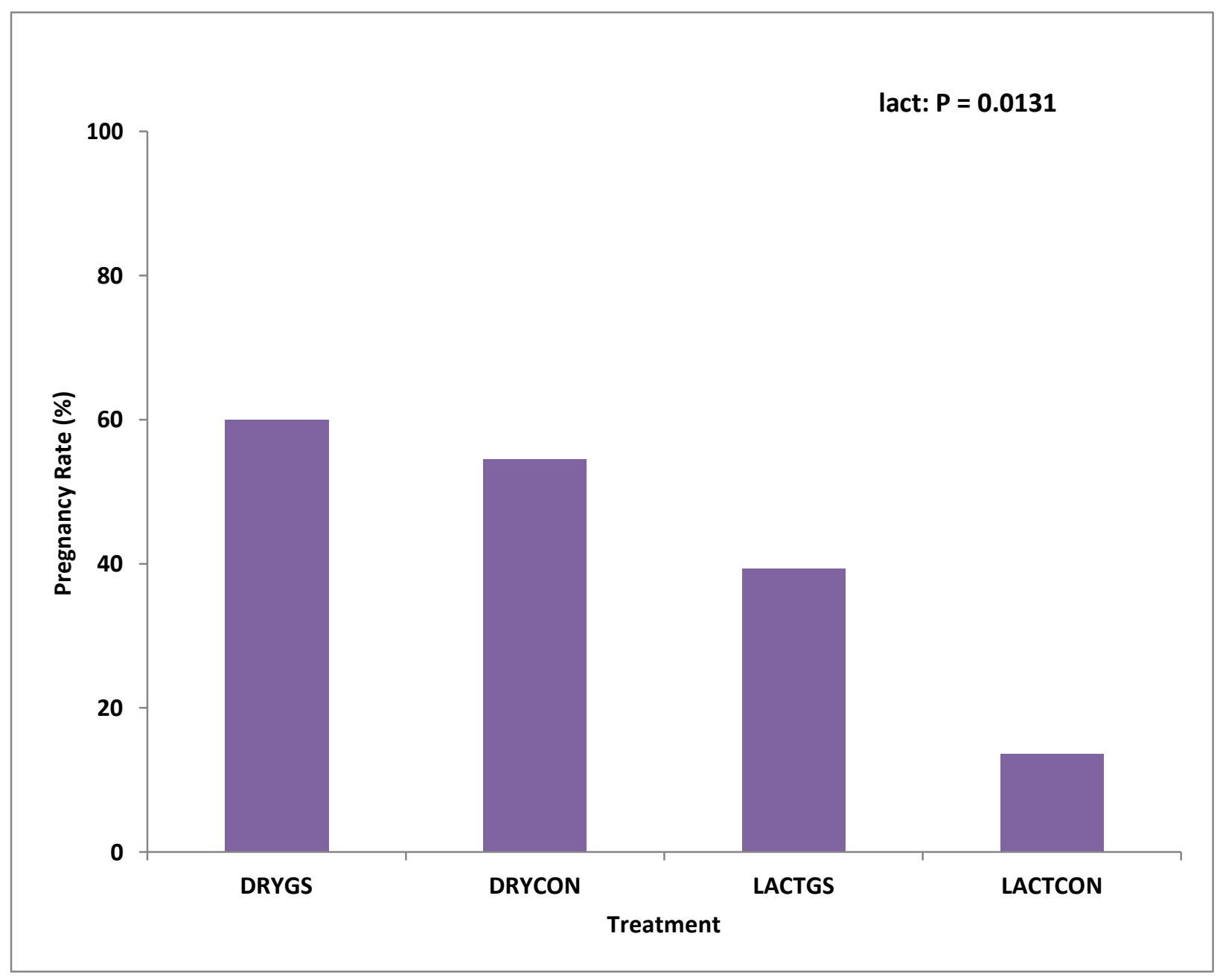

Figure 6. Pregnancy rates in dry (DRY) and lactating (LACT) ewes treated with (GS) or without (CON) a gonadotropin mixture following a 5-day progesterone pre-treatment during anestrus. Pregnancy rate was evaluated as the proportion of ewes diagnosed to be pregnant of the ewes exposed via transrectal ultrasonography 30days after ram introduction (Experiment 2). 


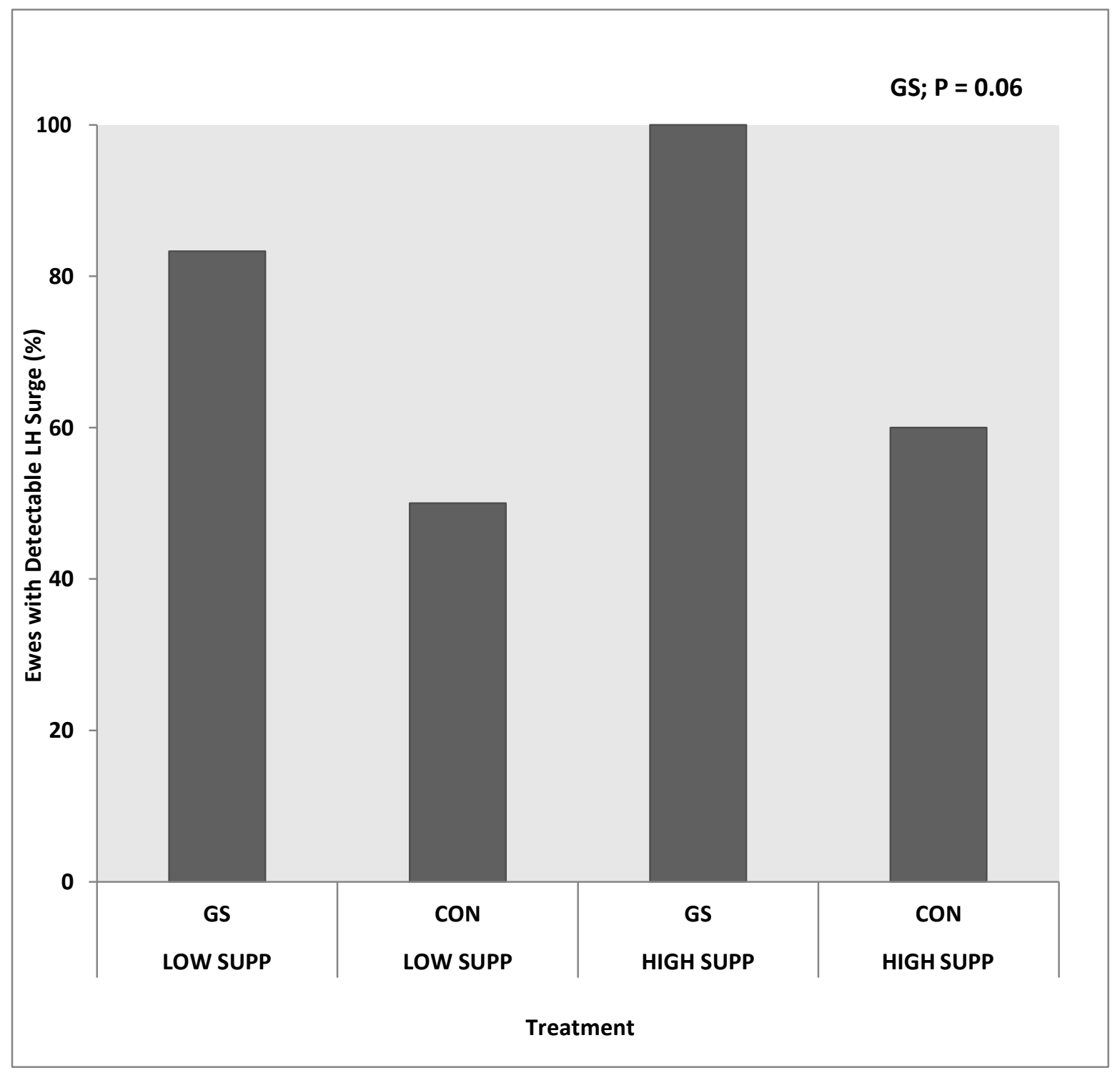

Figure 7. Effect of gonadotropin stimulation (GS) and level of feed supplementation (SUPP) on the proportion of ewes showing a LH surge following ram introduction during anestrous (Experiment 3). 
(a)

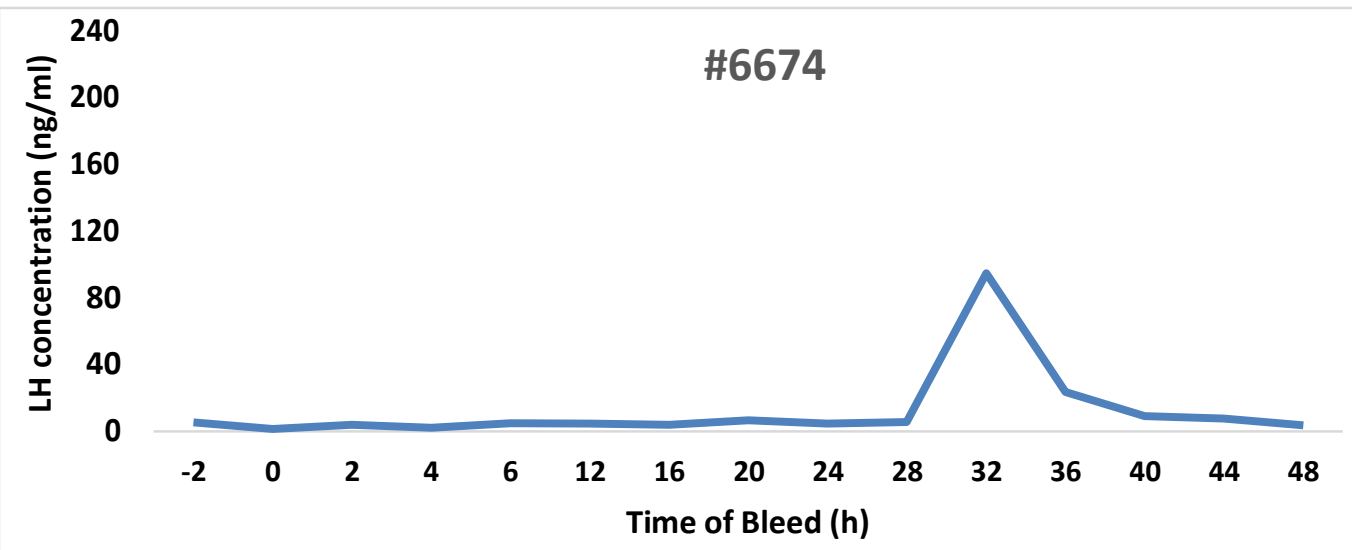

(b)

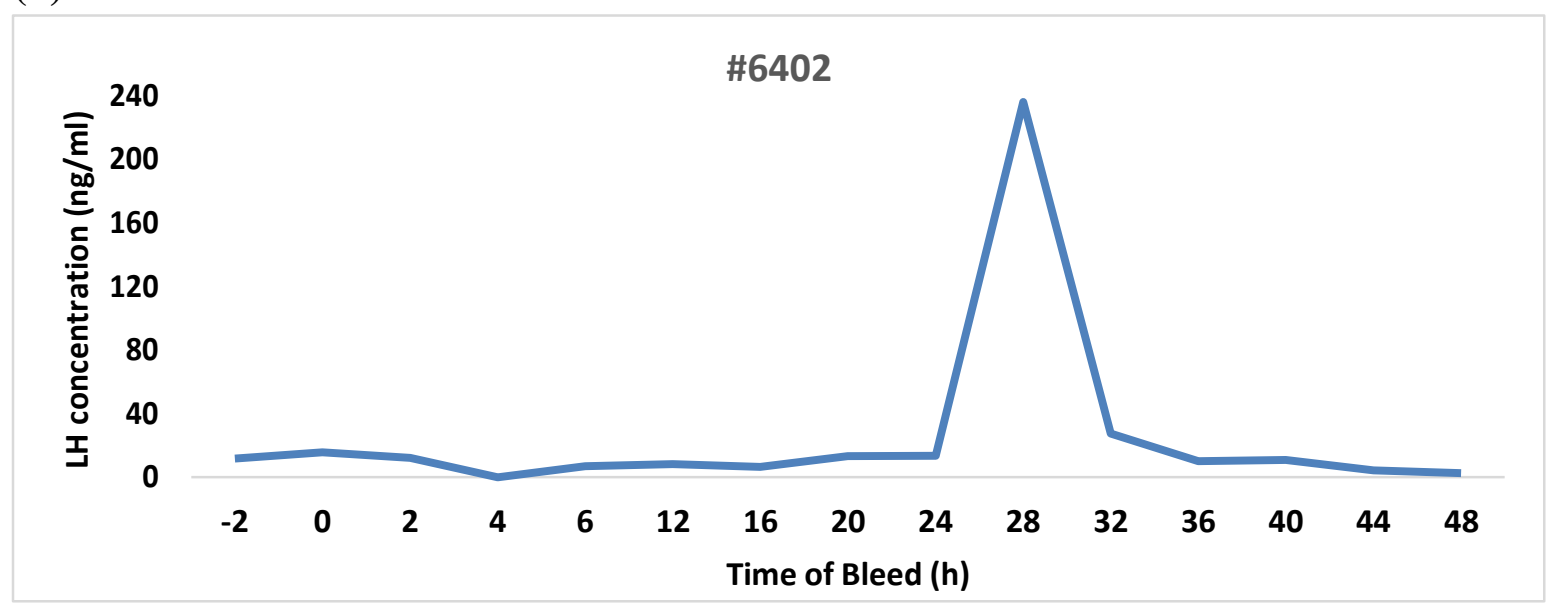

(c)

\#6433
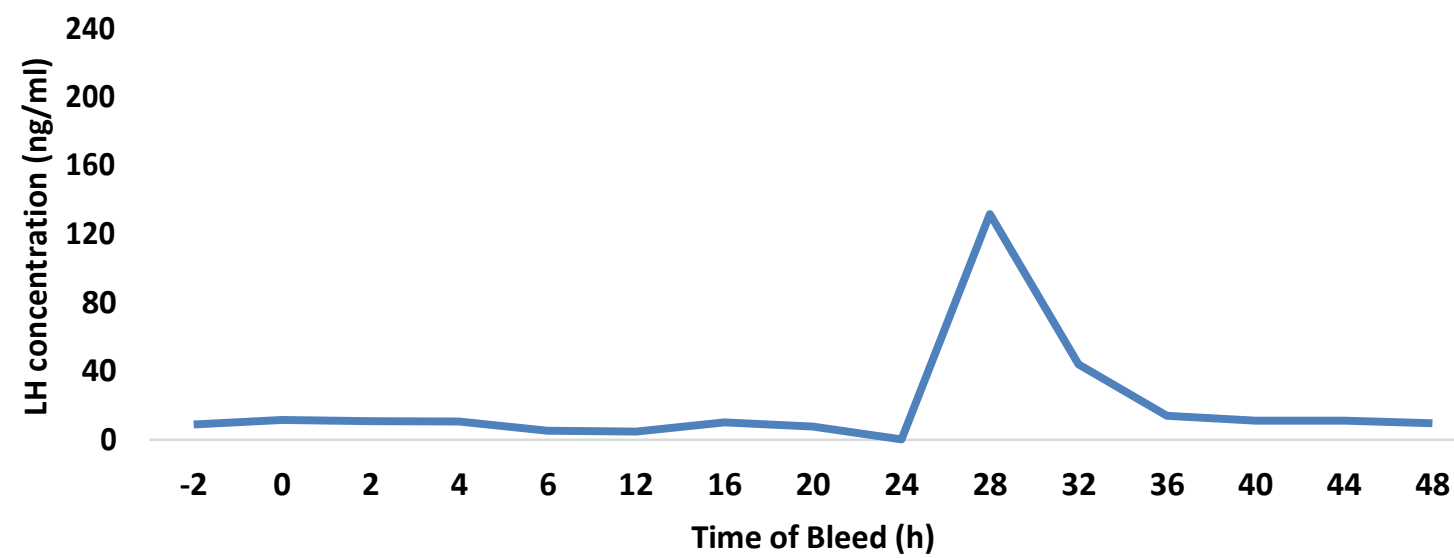
(d)

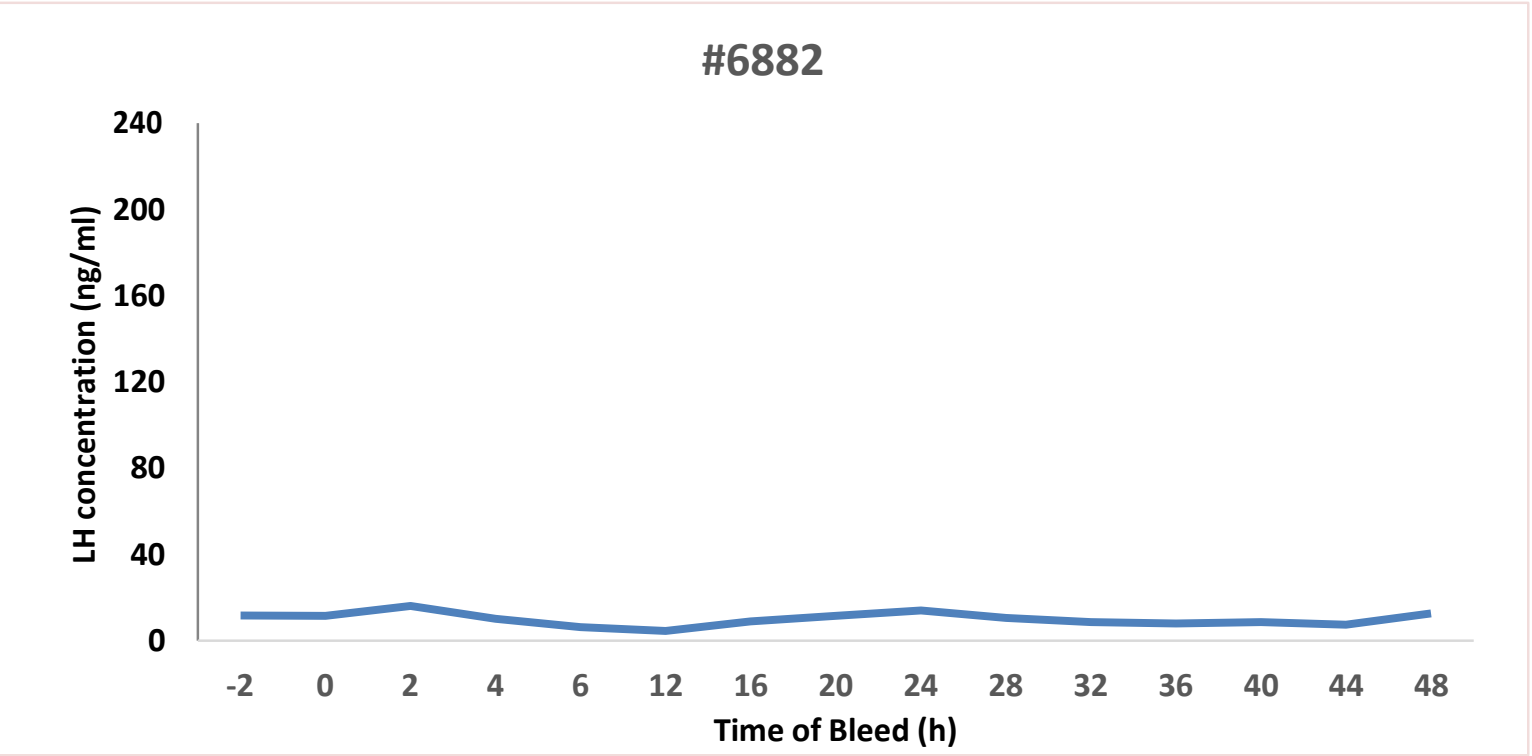

(e)

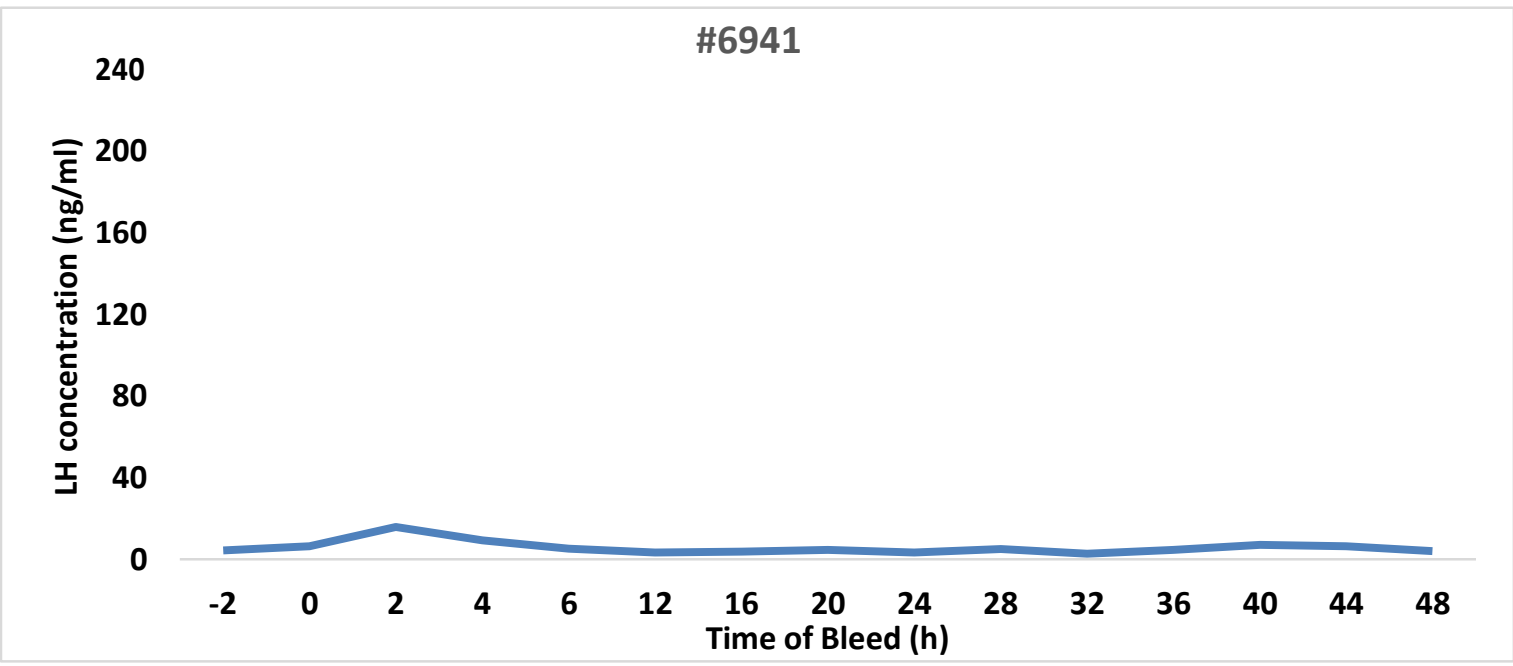

Figure 8. (a, b, c) Pattern of LH secretion in ewes \#6674, \#6402 and \#6433 with detectable LH surge, (d, e) Pattern of LH secretion in ewes \# 6882 and \#6941without detectable LH surge. The time of bleed (h) represents the 15 different time periods when blood was collected in experiment 2 and $3 ;-2$ to 48 hours after ram introduction. 

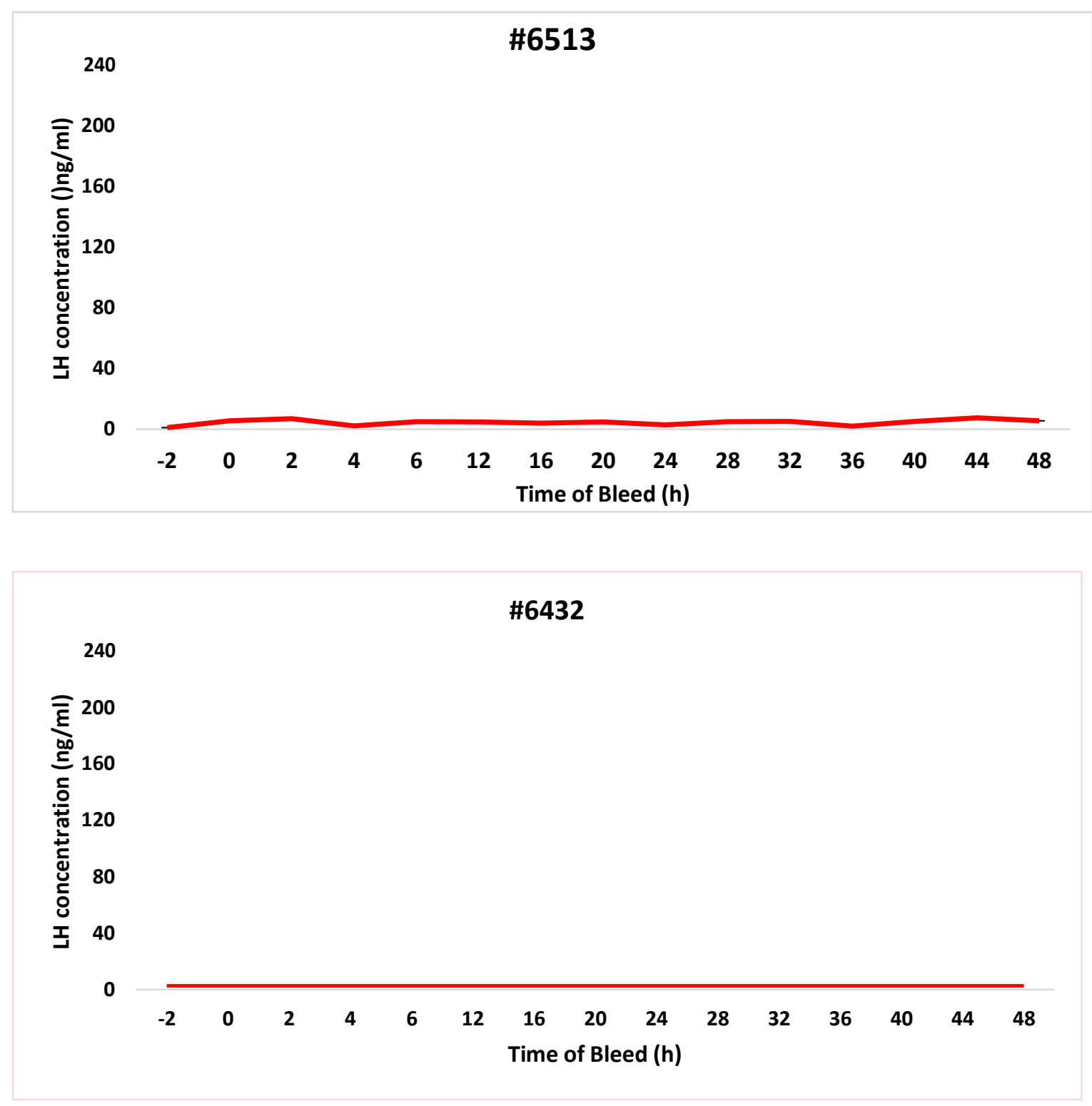

Figure 9. (a , b). The pattern of LH secretion in ewes \# 6513 and \#6432 detected in estrus, respectively and was pregnant but without a detectable LH surge. The time of bleed (h) are the various point in time (h) at which blood was collected from the ewes as stated in Figure 8 above . 


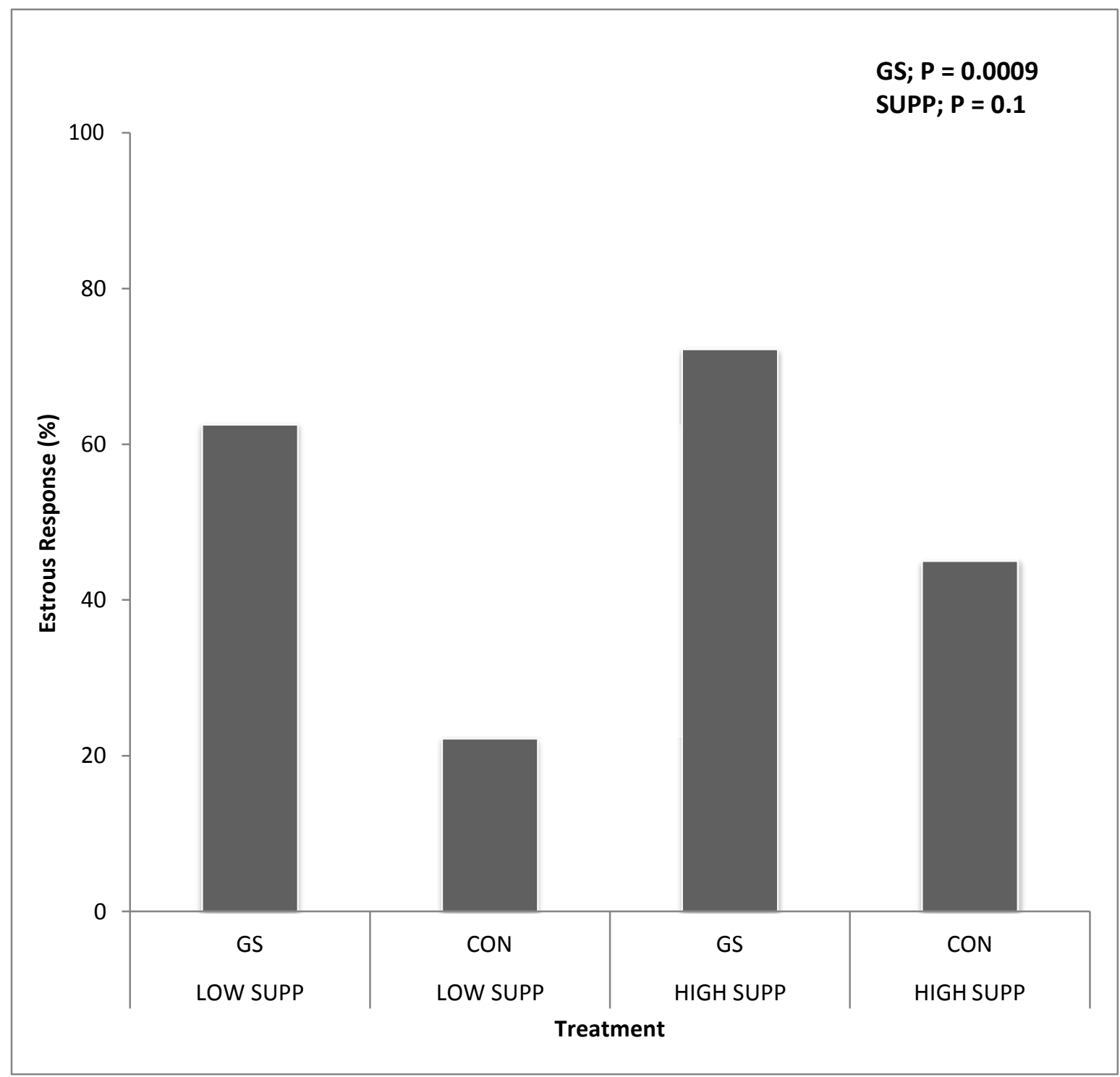

Figure 10. Effect of gonadotropin stimulation (GS) and level of feed supplementation (SUPP) on the estrous response in lactating ewes during anestrous (Experiment 3). 


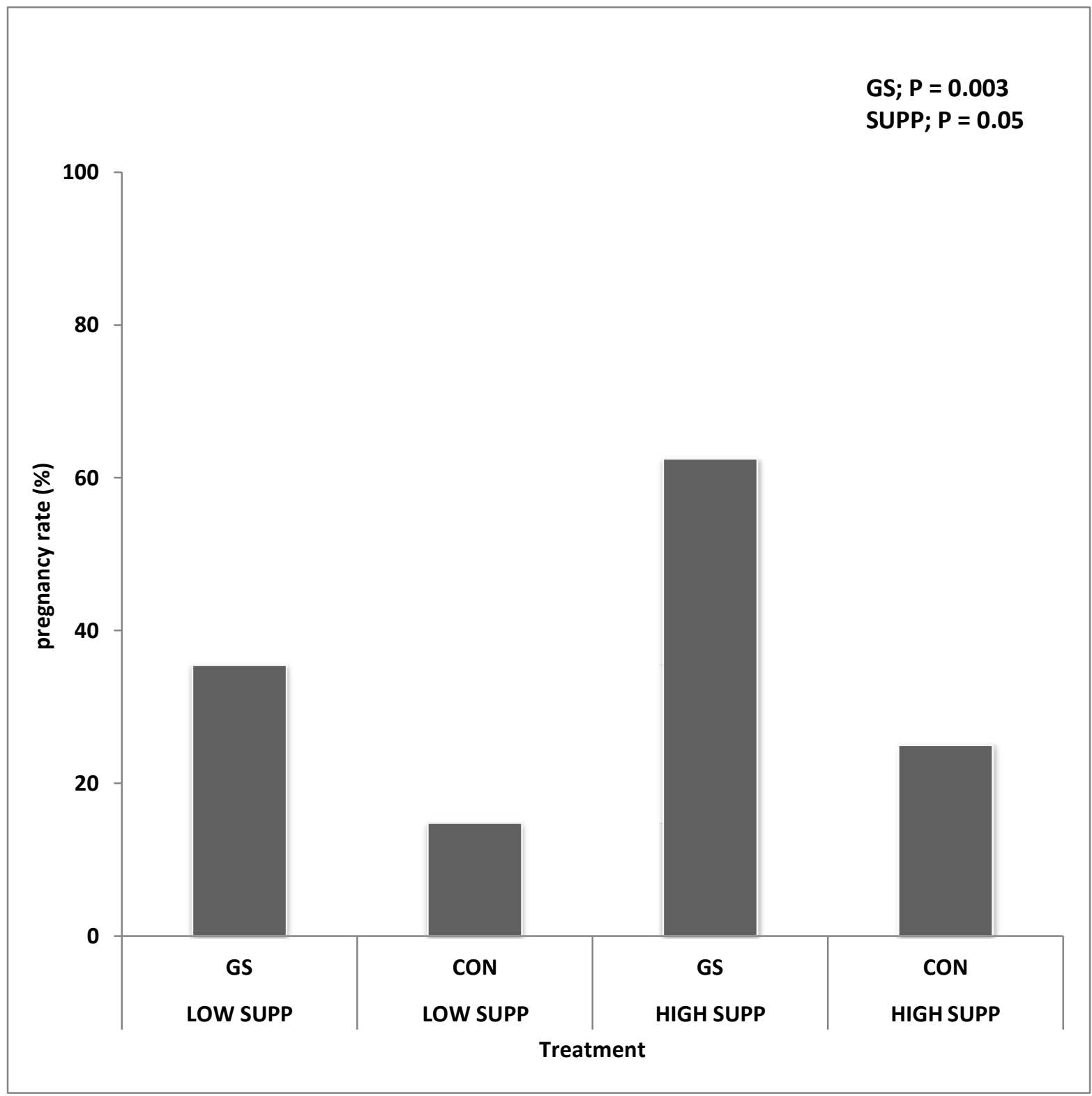

Figure 11. Effect of gonadotropin stimulation (GS) and level of feed supplementation (SUPP) on pregnancy rate in lactating ewes during anestrous (Experiment 3). Pregnancy rate was evaluated as the proportion of ewes diagnosed to be pregnant via transrectal ultrasonography 30days after ram introduction of the ewes exposed. 


\section{DISCUSSION}

Increasing the frequency of lambing requires that ewes are rebred early postpartum regardless of the season. Fall-lambing ewes can be successfully rebred early in the postpartum period (Poindron et al., 1980; Wright et al., 1989; Ungerfeld and Sanchez-Davila, 2012) when the photoperiod is still stimulatory to reproduction. However, early rebreeding of lactating ewes during seasonal anestrous has been less successful (Cognie et al., 1975; Martemucci and D’Alessandro, 2010). During seasonal anestrous, LH pulsatility (Karsch et al., 1980), amplitude of LH pulses, and pituitary LH levels are lower than during the breeding season (Clarke and Cummins, 1985). Further, in lactating ewes, the inhibitory effect of suckling and lactation might further inhibit the secretion of gonadotropins. Lactation suppresses LH secretion as a result of a profound suppression of GnRH release from the hypothalamus and a decrease in pituitary responsiveness to GnRH stimulation in the presence of a large suckling stimulus in rats (Fox and Smith, 1984). Suckling also inhibits the secretion of LH in ewes (Stellflug et al., 2001). Weaning can eliminate the suppressive effect of lactation on reproduction and facilitate rebreeding of ewes in the early postpartum period (Pevsner et al., 2010) by removal of the suckling effect and reducing the nutrient demand on the ewes. However, weaning has been known to affect the growth and survival of lambs (Knights et al., 2012; Simpson-Rastle et al., 2012; Ferda, 2014).

Successful breeding of ewes during the non-breeding season is dependent on the ability of rams to induce increase secretion of gonadotropins culminating in an LH surge and ovulation, the "ram-effect" (Knights et al., 2002). Further, fertile mating can be induced by progesterone pretreatment with or without gonadotropin stimulation at the time of progesterone withdrawal and introduction of rams (Jabbar et al., 1994; Knights et al., 2001ab; D’Souza et al., 2014, Knights et al., 2015). This raises the possibility that the poor fertility observed in lactating ewes during 
seasonal anestrous might be due to the inability of rams to induce an LH surge and that the reported positive effects of exogenous gonadotropins might be due to an enhancement of the proportion of ewes ovulating. In experiments 1 and 2 , neither the proportion of ewes with a detectable LH surge nor the peak and timing of the LH surge following ram introduction were affected by lactation status. Lactation status did not affect the proportion of ewes displaying estrus, however, both the pregnancy rate and conception rate were higher in dry ewes. Resumption of reproductive activity occurred sooner in weaned ewes as compared to lactating ewes (Mallampati et al.1971; Restall, 1971) and low fertility was also reported in lactating (Hulet and Foote, 1967) and early postpartum ewes (Restall et al., 1978). Assuming a similar proportion of dry and lactating ewes ovulated, the current finding suggests that the environment necessary for fertilization and or maintenance of the early embryo might be compromised in lactating ewes bred during seasonal anestrous.

Gonadotropin stimulation increased or tended to increase the proportion of ewes with a detectable LH surge following introduction of rams independent of lactation status or level of nutritional supplementation. The mean peak LH concentration and the time to peak concentration in ewes with detectable LH surge in this study were not affected by any of the treatments or their interaction in this study. The time to peak concentration of LH surge in this study is similar to what was reported in ewes introduced to rams during late anestrus (Chanvallon et al., 2011) and during the mid-breeding season (Ungerfeld et al.,2005). The mean peak LH concentration in this study is comparable to the finding of Knights et al. (2002) in progesterone pretreated, raminduced ewes during anestrous. As noted earlier, both pituitary content and gonadotropin secretion is suppressed during anestrous which might explain why the proportion of ewes with a detectable LH surge following ram introduction was lower in ewes not receiving, than those 
receiving, GS. These findings suggest that a major benefit of using exogenous gonadotropins in estrus induction protocols might be to increase the proportion of ewes ovulating.

Gonadotropin stimulation increased the estrous response and the magnitude of the effect tended to be greater in lactating ewes (Experiment 2), but was independent of the level of supplementation (Experiment 3). The pregnancy rate in lactating ewes was also increased by GS (Experiment 3). Interestingly GS did not affect conception rate, which indicates that the increases in estrus response, as measured by evidence of mating, accounts for the higher pregnancy rate observed in gonadotropin supplemented females. Estrogen production or the responsiveness to estrogen might be compromised in lactating ewes during anestrous (Shevah et al., 1974) necessitating additional gonadotropin support beyond that induced by ram introduction.

Lactation has a high metabolic demand and can result in significant weight loss (Mbayahaga et al., 1998), and lower body condition scores which in turn reduce the secretion of gonadotropins (Haresign, 1981), delays and reduces the amplitude of the LH surge (Smart et al., 1994), which prevents ovulation (McNeilly, 1997) and negatively impacts fertility (Fletcher, 1973; Hunter and Van Aarde, 1973; McNeilly, 2001). Higher live weights due to an improved plane of nutrition can increase ovulation rate, fertility and embryo survival (Smith, 1991, Scaramuzzi et al., 2006; Ferguson et al., 2011, Oldham et al., 2011). Mennasol et al. (2012) reported that feed supplementation (high plane of nutrition) can compensate for the weight loss during lactation and also bring about a resumption of ovarian activity. There is also a consistent reduction in the duration of seasonal anestrous in ewes maintained at higher body condition score $(\geq 2.7$; Forcada et al., 1992). In the current study, increasing the plane of nutrition of lactating ewes early postpartum did not increase the proportion of females with a detectable LH surge which may be 
due to the neuroendocrine effect of suckling stimulus. However animals on the high plane of nutrition had higher pregnancy rates, and tended to have a higher estrous response. Together these findings suggest that increasing the plane of nutrition might not be necessary to increase the proportion of females ovulating but might be acting to increase the expression of estrus and early embryonic survival.

Across experiments almost $50 \%$ of lactating Katahdin ewes exhibited an LH surge following ram introduction during anestrous without gonadotropin stimulation. Despite this, the estrous response and pregnancy rate were low which suggests that the combined negative effect of lactation and anestrous season is still evident in Katahdin sheep.

Previous studies have not fully evaluated the potential synergistic effect of gonadotropin and nutritional supplementation on rebreeding lactating ewes early postpartum. In the current study the interaction between plane of nutrition and gonadotropin stimulation on pregnancy rates in lactating ewes was not significant. However, the $63 \%$ first service pregnancy rate achieved with the use of a high plane of nutritional supplementation and gonadotropin stimulation was comparable to that achieved in dry ewes during anestrous (Tritschler et al., 1991; Knights et al., 2001a; Dogan and Nur, 2006; Knights et al., 2015) and during the breeding season (Ungerfeld and Sanchez-Davila, 2012). In conclusion, during anestrous, early postpartum fertility is reduced by lactation in Katahdin ewes, but fertility in lactating ewes can be increased to that of dry ewes with nutritional supplementation and by providing exogenous gonadotropin as part of the EIP. 


\section{IMPLICATIONS}

Nutritional supplementation with exogenous gonadotropin effectively improved fertility rate in lactating ewes in their early post-partum period and can be used to successfully breed lactating ewes during anestrous season.

The combination of both treatments may therefore be appropriate for use in accelerated lambing program. Rebreeding lactating ewes in spring (non-breeding season) would be useful to avoid early weaning of lambs which is reportedly deleterious to the lambs.

On annual production basis, there is an increase in the cost of production associated with out-ofseason breeding. However, this can be offset by;

i. Increasing the proportion of ewes lambing

ii. Higher market value (selling prices) of lambs, as a result of declining lamb sales during the winter and spring (Singh-Knights et al., 2004).

Therefore, increasing frequency of lambing by breeding lactating ewes out-of-season can increase the productivity and profitability of sheep operation and so contribute to revitalizing the sheep industry in the US. 


\section{REFERENCES}

Acritopoulou S., Haresign W. (1980). Response of ewes to a single injection of an analogue of PGF-2 alpha given at different stages of the oestrous cycle. J. Reprod Fertil. 58(1): 219221.

Adams, N.R., Briegel, J.R., Sanders, M.R., Blackberry, M.A., Martin, G.B. (1997). Level of nutrition modulates the dynamics of oestradiol feedback on plasma FSH in ovariectomized ewes. Anim. Reprod. Sci. 47, 59-70.

Ainsworth L., Shrestha J.N.B (1985). Effect of PMSG dosage on the reproductive performance of adult ewes and ewe lambs bred at a progestagen-PMSG synchronized estrus. Theriogenology. 24(5): $479-487$.

Allison A.J, Kelly R.W, Lewis J.S, Binnie D.B. (1975). Preliminary studies on the efficiency of mating of ewe hoggets. Proceedings of the NZ Society of Animal Production 35: 83-90.

Al-Mauly, N. Z. N, Bryant, M. X, and Cunningham, F. J. (1991). Effect of the introduction of rams on the pulsatile release of luteinizing hormone and the onset of reproductive activity in ewe lambs. Anim. Prod. 53,209-214.

American Sheep Industry Association Production Education and Research Council.(2002). Sheep Production Handbook. C\&M Press, Denver Colorado, US.

Armstrong D. T., Pfitzner A. P., Warnes G. M., Ralph M. M., Seamark R. F. (1983). Endocrine responses of goats after induction of superovulation with PMSG and FSH. J. Reprod. Fert. 67: 395-401.

BANR. (2008). Changes in the Sheep Industry in the united States- Making the transition from tradition. National Research Council. http://www.nap.edu/read/12245/chapter/3. 
Barrell G.K, Moenter S.M, Caraty A, Karsch F.J. (1992). Seasonal changes of gonadotropinreleasing hormone secretion in the ewe. Biology of Reproduction. 46:1130-1135.

Baril, G., Freitas V. J., Saumande J. (1998). Progestagen treatments for the induction / synchronisation of oestrus in goats: update on recent research. Revue Med. Vet. 149:359366.

Boujenane I., Berrada D., Mihi S., Jamai M. (1998). Reproductive performance of ewes and preweaning growth of lambs from three native Moroccan breeds mated to rams from Moroccan and improved breeds. Small Ruminant Research. 27; 203-208.

Boukhliq, R., Adams, N.R., Martin, G.B.(1996). Effect of nutrition on the balance of production of ovarian and pituitary hormones in ewes. Anim. Reprod. Sci. 45, 59-70.

Brown B.W (1994). A review of nutritional influences on reproduction in boars, bulls and rams. Reprod Nutr Dev. 34: 89-14.

Burfening P.J, Van Horn J.L (1970). Induction of fertile oestrus in prepubertal ewes during the anoestrous season. J. Reprod Fertil. 23(1): 147-150.

Chanvallon A., Scaramuzzi R.J., Fabre-Nys C. (2010). Early sexual experience and stressful conditions affect the response of young ewes to the male. Physiology \& behavior. 99 : 457-465.

Chanvallon A, Sagot L, Pottier E, Debus N, François D, (2011). New insights into the influence of breed and time of the year on the response of ewes to the 'ram effect'. Animal 5: 15941604.

Chemineau P., Malpaux B., Delgadillo J.A, Guérin Y., Ravault J.P, Thimonier J, Pelletier J. (1992). Control of sheep and goat reproduction: use of light and melatonin. Animal Reproduction Science 30, 157-184. 
Cognie Y, Hernandez-Barreto M and Saumande J (1975). Low fertility in nursing ewes during the non-breeding season. Annales de Biologie Animale, Biochimie, Biophysique 15; 329-343.

Dahl, G. E, Buchanan B.A, Tucker H.A. (2000). Photoperiodic effects on dairy cattle: A review. J. Dairy Sci., 83: 885-893.

Daniel, J.A., Sterle, S.W., McFadin-Buff, E.L., Keisler, D.H. (2001). Breeding ewes out-ofseason using melengestrol acetate, one injection of progesterone, or a controlled internal drug releasing device. Theriogenology. 56:105-110.

Dardente Hugues (2011). Melatonin-Dependent Timing of Seasonal Reproduction by the Pars Tuberalis: Pivotal Roles for Long Daylengths and Thyroid Hormones. Journal of Neuroendocrinology. .24(2):249-66.

DeNicolo G., Morris S.T., Kenyon P.R., Morel P.C.H. (2006). Effect of weaning pre- or postmating on performance of spring-mated ewes and their lambs in New Zealand. N. Z. J. Agric. Res. 49 : 255-260.

Dikmen S., Turkmen I.I., Ustuner H., Alpay F., Balci F., Petek, M. , Ogan M. (2007) Effect of weaning system on lamb growth and commercial milk production of Awassi dairy sheep. Czech J. Anim. Sci. 52 (3): 70-76.

Dobson H., Fergani C., Routly J.E., Smith, R.F. (2012). Effects of stress on reproduction in ewes. Anim. Reprod. Sci. 130: 135-140.

Dogan I, Nur Z. (2006). Different estrous induction methods during the non-breeding season in Kivircik ewes. Vet Med, 51:133-138. 
Donovan, A., O’Callaghan, D., Boland, M.P., Karsch, F.J., Roche, J.F. (1991). The relative importance of social signals from ewes and rams in influencing the timing of the breeding season of ewes. J. Reprod. Fertil. Abstr. Series 7: 30.

D'Souza, K.N. (2013). Effects of a Gonadotropin Mixture on Reproductive Success in Progesterone- Treated Non-Lactating Anestrous Ewes. Unpublished M.S. thesis, West Virginia University. 1-68.

D’Souza K. N., Rastle-Simpson S.L., Redhead A.K., Baptiste Q.S., Smith B., Knights M. (2014). Gonadotropin stimulation using P.G. $600^{\circledR}$ on reproductive success of non-lactating anestrous ewes. Anim Reprod sci. 148(3-4):115-120.

Dumas, Carol Ryan. (2011). “U.S. sheep and lamb markets soar”. Capital Press. 19 May 2011 http://www.capitalpress.com/lvstk/CRD-lamb-market-w-chart-052011.

Dutt, R. H. (1954). Fertility rate and embryonic death loss in ewes early in the breeding season. J. Anim. Sci. 13:464.

Dutt, R.H., Bush, F. (1955). The effect of low environmental temperature on initiation of the breeding season and fertility in sheep. J. Anim. Sci. 14: 885-897.

Dwyer, C.M. (ed) (2008). The Welfare of Sheep, Springer, New York.

Dynes R.A., Moss R. A., Bray, A. R., McAnulty R.W. (2006). Effect of weaning age on growth rates of lambs infected by gastrointestinal parasites. Proceedings of the New Zealand Grassland Association 68: 139-142.

Fabre-Nys C., Kendrick K.M., Scaramuzzi R. J. (2015). The "ram effect": new insights into neural modulation of the gonadotropic axis by male odors and socio-sexual interactions. Front.Neurosci. 9: 111. 
Ferguson M.B, Thompson A.N, Gordon D.J, Hyder M.W, Kearney G.A, Oldham C.M, Paganoni B.L (2011). The wool production and reproduction of Merino ewes can be predicted from changes in liveweight during pregnancy and lactation. Animal Production Science. 51 :763-775

Fletcher, I.C. (1973) Effect of lactation, suckling and oxytocin on post-partum ovulation and oestrus in ewes. Reprod. Fert. 3: 293-298.

Fogarty N.M, Hall D.G, Dawe S.T, Atkinson W, Allan C. (1992). Management of highly fecund ewe types and their lambs for 8-monthly lambing. 1. Effect of lamb weaning age on ewe reproductive activity in spring. Aust J Exp Agric. 32: 421-8.

Forcada, F., Abecia, J.A. and Sierra, I. (1992). Seasonal changes in oestrous activity and ovulation rate in Rasa Aragonesa ewes maintained at two different body condition levels. Small Rumin. Res. 8: 313-324.

Forcada F, Abecia J. (2006). The effect of nutrition on the seasonality of reproduction in ewes. Reproduction Nutrition Development, EDP Sciences, 46 (4): 355-365.

Foster, D.L., Lemons J.A, Jaffe R.B., Niswender G.D. (1975). Sequential patterns of circulating luteinizing hormone and follicle stimulating hormone in female sheep from early postnatal life through the first estrous cycles. Endocrinology. 97:985-994.

Fox S.R., Smith S.M. (1984). The Suppression of Pulsatile Luteinizing Hormone Secretion during Lactation in the Rat. Endocrinology. 115(6): 2045-2051.

Gaskin C.T, Snowder G.D, Westman M.K, Evans M. (2005). Influence of body weight, age and weight gain on fertility and prolificacy in four breeds of ewe lambs. Journal of Animal Science 83: 1680- 1689 
Geenty K.G., Sykes A.R. (1983): Feed requirements of the ewe and lamb between birth and weaning. In: Anim. Industries Workshop, Lincoln College, Canterbury, NZ. Lamb Growth. 95-104.

Goding, J.R., Catt, K.J., Brown, J.M., Kaltenbach, C.C., Cumming, I.A., Mole, B.J. (1969). Radioimmunoassay for ovine luteinizing hormone. Secretion of luteinizing hormone during estrus and following estrogen administration in the sheep. Endocrinology. 85:133142.

Godley, W. C., Wilson R. L., Hurst V. (1966). Effect of controlled environment on the reproductive performance of ewes. J. Anim. Sci. 25:212.

Goodman R.L, Bittman E.L, Foster D.L, Karsch F.J (1982). Alterations in the control of luteinizing hormone pulse frequency underlie the seasonal variation in estradiol negative feedback in the ewe. Biol Reprod. 27: 580-589.

Goodman R.L, Coolen L.M, Anderson G.M, Hardy S.L, Valent M, Connors J.M, Fitzgerald M.E, Lehman M.N. (2004). Evidence that dynorphin plays a major role in mediating progesterone negative feedback on gonadotropin-releasing hormone neurons in sheep. Endocrinology. 145(6):2959-67.

Gonzalez R., Poindron P., Signoret J.P. (1988).Temporal variation in LH and testosterone responses of rams after the introduction of oestrous females during the breeding season. J. Reprod. Fertil. 83: 201-208.

Gonzalez R., Orgeur P., Poindron P., Signoret J.P. (1991). Female effect in sheep. I. The effects of sexual receptivity of females and the sexual experience of rams. Reprod. Nutr. Develop., 31: 97-102. 
Gonzalez-Bulnes, A., J. Santiago-Moreno, M. J. Cocero and A. Lopez-Sebastian. (2000). Effects of FSH commercial preparation and follicular status on follicular growth and superovulatory response in Spanish Merino ewes. Theriogenol. 54:1055-1064.

Gonzalez R. E., Labuonora D., Russel A. J. E. (1997). The effects of ewe live weight and body condition score around mating on production from four sheep breeds in extensive grazing systems in Uruguay. Animal Science. 64: 139-145.

Gordon I. (1963). The induction of pregnancy in the anestrous ewe by hormonal therapy. 1. Progesterone-pregnant mare's serum therapy during the breeding season. Ibid. 60:31-41.

Gordon, I. ( 1997). Controlled Reproduction in Sheep and Goats. Cambridge University Press, Wallingford, $U K$.

Gundogan M, Uçar M, Tekerli M. (2002). A study on morphometric measurements of testes and spermatologic features of rams kept under Afyon conditions. J Vet Sci. 18: 63-67.

Gundogan, M., Baki, D. Yeni, D. (2003). Review: Reproductive Seasonality in Sheep. ACta Agric.Scand., Sect.A, Animal Sci. 53: 175-179.

Gunn R.G, Smith W.F, Senior A.J, Barthram E, Sim D.A, Hunter E.A, (1991). Pre-mating herbage intake and the reproductive performance of North Country Cheviot ewes in different levels of body condition. Anim Prod 52: 149- 156.

Hamra, A.H., Massri, Y.G., Marcek, J.M., and Wheaton, J.E. (1986). Plasma progesterone levels in ewes treated with progesterone-controlled internal drug-release dispensers, implants and sponges. Anim. Reprod. Sci. 11: 187-194.

Hashem N.M., El-Zarkouny S.Z, Taha T.A., Abo-Elezz. Z.R. (2011). Effect of season, month of parturition and lactation on estrus behavior and ovarian activity in Barki x Rahmani crossbred ewes under subtropical conditions. Theriogenology 75 1327-1335. 
Haresign W. (1981). The influence of nutrition on reproduction in the ewe. 2. Effects of undernutrition on pituitary responsiveness to luteinizing hormone-releasing hormone stimulation. Anim. Prod. 32 (3); 257-260.

W. Haresign (1992). Responses of ewes to melatonin implants: importance of the interval between treatment and ram introduction on the synchrony of mating, and effects on ovulation rate. Animal Production. 54(1): 41 - 45.

Haynes, N.B. \& Schanbacher, B.D. (1983). The control of reproductive activity in the ram. In Sheep Production, Ed. W. Haresign. Butterworth, London. 431-451.

Hamadani H., Khan H.M, Khan A.A. (2013). Effect of Photoperiod in Domestic Animals. International Journal of Modern Plant \& Animal Sciences. 1(3): 116-122.

Hötzel M.J, Caraty A, Martin G.B (1997). Effects of nutrition on testicular growth in mature Merino rams actively immunized against GnRH. J Reprod Fertil. 110(2):307-13

Hulet C.V, Foote WC. (1967). Induction of fertile estrus in lactating and dry anestrous ewes using oral progestogens and repeated PMSG treatment. J Anim Sci.23:545-8.

Hulet, C. V., Voightlander, H.P., Pope, A.L., and Casida, L.E. (1956). The nature of early-season infertility in sheep. J. Anim. Sci. 15: 607-616.

Hulet, C.V., Blackwell, R.L., Ercanbrack, S.K.(1964). Observations on sexually inhibited rams. J. Anim. Sci. 23: 1095-1097.

Hunter, G.L. \& Van Aarde, I.M.R. (1973). Influence of season of lambing on post-partum intervals to ovulation and oestrus in lactating and dry ewes at different nutritional levels. Reprod. Fert. 32, 1-8.

Hutchinson, J.S.M., Robertson, H.A. (1966).The growth of the follicle and corpus luteum in the ovary of the sheep. Res. Vet. Sci. 7: 17-24. 
Illius A.W., Haynes N.B., Lamming G.E. (1976). Effect of ewe proximity on peripheral plasma testosterone levels and behaviour in the ram. J. Reprod. Fertil. 48: 25-32.

lnskeep E.K. Murdoch W.J. (1980). Relation of ovarian functions to uterine and ovarian secretion of prostaglandins during the estrous cycle and early pregnancy in the ewe and cow. In: Greep RO (ed.) Reproductive Physiology Ill International Review of Physiology. Baltimore: University Park Press. 22: 325-356.

Iposu, S.O. (2007). Effect of suckling on response to nematode parasites in young lambs. $\mathrm{PhD}$ thesis, Lincoln University, Canterbury, New Zealand.

Jabbar, G., S. H. Umberger, and G. S. Lewis. (1994). Melengestrol acetate and norgestomet for the induction of synchronized estrus in seasonally anovular ewes. J. Anim. Sci. 72:30493054.

Jabbour, H. N., and G. Evans. (1991). Ovarian and endocrine responses of Merino ewes following treatment with PMSG and GnRH or PMSG antiserum. Anim. Reprod. Sci. 24:259-270.

Jansen H.T, Jackson G.L (1993). Circannual Rhythms in the Ewe: Patterns of Ovarian Cycles and Prolactin Secretion under Two Different Constant Photoperiods. Biology of Reproduction 49: 627-634.

Johnson, M. H. (2007). Essential Reproduction, Sixth edition. Blackwell Publishing, U.S.A.

Jones, K.G. (2004). Trends in the U.S. Sheep Industry. Agriculture Information Bulletin Number 787, 1-34.

Karakuş F. (2014) Weaning Stress in Lamb. Journal of International Scientific Publications: Agriculture and Food. 2: 165 - 170. Published at: http://www.scientific-publications.net. 
Karsch, F. J., Goodman, R. L., and Legan, S. J. (1980). Feedback basis of seasonal breeding: Test of an hypothesis. J. Reprod. Fert. 58, 521-535.

Karsch .FJ, Bittman E.L, Foster D.L, Goodman R.L, Legan S.J, Robinson J.E (1984). Neuroendocrine basis of seasonal reproduction. Recent Prog Horm Res. 40:185- 232.

Karsch, F.J. (1984). Endocrine and environmental control of oestrous cyclicity in sheep. In: Reproduction in Sheep. Cambridge University Press, Cambridge, pp. 10-15.

Karsch F.J, Moenter S.M. (1990). Neuroendocrine regulation of seasonal breeding cycles in the ewe. J Exp Zool Suppl. 4:17-21.

Karsch F.J, Dahl G.E, Evans N.P, Manning J.M, Mayfield K.P, Moenter S.M, Foster D.L. (1993). Seasonal changes in gonadotropin-releasing hormone secretion in the ewe: alteration in response to the negative feedback action of estradiol. Biol Reprod. 49: 13771383.

Kassem R., Owen J.B., Fadel I. (1989). The effect of pre-mating nutrition and exposure to the presence of rams on the onset of puberty in Awassi ewe lambs under semi-arid conditions. Anim. Prod. 48: 393-397.

Kennedy D. (2012). Sheep Reproduction Basics and Conception Rates. Retrieved from http://www.omafra.gov.on.ca/english/livestock/sheep/facts/12-037.pdf.

Kenyon P.R, Morel P.C.H, Morris S.T, West D.M. (2005). The effect of individual liveweight and use of teaser rams prior to mating on the reproductive performance of ewe hoggets. New Zealand Veterinary Journal 53: 340-343.

Knight, T.W., Lynch, P.R. (1980). Source of ram pheromones that stimulate ovulation in the ewe. Anim. Reprod. Sci. 3:133-136. 
Knight, T.W. (1983). Ram induced stimulation of ovarian and oestrous activity in anoestrous ewes-a review. Proc. N.Z. Soc. Anim. Prod. 43: 7-11.

Knight T.W., Hall D.R.H., Wilson L.D. (1983a). Effect of teasing and nutrition on the duration of the breeding season in Romney ewes. Proceedings of the New Zealand Society of Animal Production. 43: 17 - 19.

Knight, T.W., Tervit, H.R. \& Lynch, P.R. (1983b). Effect of boar pheromones, rams' wool and the presence of bucks on ovarian activity in anovular ewes early in the breeding season. Anim. Reprod. Sci. 6: 129-134.

Knight T.W, McWilliam W.H, Kannegieter S.G, Sorensen E.S, Ridland C.J, Gibb M. (1989). Mating Romney ewes in November-December using CIDRs and pregnant mare serum gonadotropin. Proceedings of the New Zealand Society of Animal Production 49: 255260.

Knights M, Hoehn T, Lewis P.E, Inskeep E.K. (2000). Effectiveness of intravaginal progesterone inserts and FSH to induce synchronized estrus and increase lambing rate in anestrous ewes. Abstract presented at the Midwestern Section ASAS and Midwest Branch ADSA 2000 Meeting, Des Moines, IA. J Anim Sci. 78 (Suppl 2) 216 Abstr.

Knights M., Hoehn T., Lewis P. E., Inskeep E.K. (2001a). Effectiveness of intravaginal progesterone inserts and FSH for inducing synchronized estrus and increasing lambing rate in anestrous ewes. J Anim Sci. 79:1120-1131.

Knights M., Maze T.D., Bridges P.J., Lewis P.E, Insleep E.K. (2001b). Short-term treatment with a controlled internal drug releasing (CIDR) device and FSH to induce fertile estrus and increase prolificacy in anestrous ewes. Theriogenology. 55(5): 1181-1191. 
Knights, M., Baptiste, Q.S., and Lewis, P.E. (2002). Ability of ram introduction to induce LH secretion, estrus and ovulation in fall-born ewe lambs during anestrus. Anim. Reprod. Sci. 69: 199-209.

Knights, M., Siew N., Ramgattie R., Singh-Knights D., Bourne G. (2011). Effectiveness of a Short-Term Treatment with Progesterone Injections on Synchrony of Lambing and Fertility in Tropical Hair Sheep. Animal Reprod Sci.126: 70-75.

Knights M., Siew, N., Ramgattie R., Singh-Knights D, Bourne G. (2012). Effect of time of weaning on reproductive performance of ewes and growth of lambs in Barbados Blackbelly sheep reared under a tropical photoperiod. Small Ruminant Research. 103: 205-210.

Knights M, Redhead A, D'Souza K, Baptiste Q. (2015) Effect of stimulation with a gonadotropin mixture on reproductive outcome in nulliparous ewes bred during seasonal anestrus and early breeding season. Anim Reprod Sci. 159;198-204.

Land, R.B., Pelletier, J., Thimonier, J., Mauléon, P.( 1973). A quantitative study of genetic differences in the incidence of oestrus, ovulation and plasma luteinizing hormone concentration in the sheep. J. Endocrinol. 58: 305-317.

Lassoued, N., Khaldi G., Cognie Y., Chemineau P., Thimonier J. (1995). Effect of progesterone on ovulation rate and oestrus cycle length induced by the male effect in the Barbarine ewe and Tunisian local goat. Reprod. Nutr. Dev. 35:415-426.

Laster D.B, Glimp H.A (1974). Influence of breed on response to exogenous hormones in estrous and anestrous ewes. J. Anim. Sci. 39(6): 1129-1135.

Lees, J. L. (1966). Variations in the time of onset of the breeding season in Clun ewes. J. Agr. Sci. (Camb.). 67:173. 
Legan S.J, Karsch F.J, Foster D.L. (1977). The endocrine control of seasonal reproductive function in the ewe: a marked change in response to the negative feedback action of estradiol on luteinizing hormone secretion. Endocrinology. 101: 818-824.

Legan SJ, Karsch FJ. (1979) Neuroendocrine regulation of the estrous cycle and seasonal breeding in the ewe. Biol Reprod. 20: 74-85.

Legan SJ, Karsch FJ (1980). Photoperiodic control of seasonal breeding in ewes: modulation of the negative feedback action of estradiol. Biol Reprod. 23: 1061- 1068.

Lewy, A. J., Wehr, T. A., Goodwin, F. K. (1980). Light suppresses melatonin secretion in humans. Science. 210(4475): 1267-9.

Leyva V, Buckrell B.C, Walton J.S. (1998) Follicular activity and ovulation regulated by exogenous progestagen and PMSG in anestrous ewes. Theriogenology. 50(3):377-93.

Lincoln, G.A., Davidson, W. (1977). The relationship between sexual and aggressive behaviour, and pituitary and testicular activity during the seasonal sexual cycle of rams, and the influence of photoperiod. J. Reprod. Fertil. 49, 267-276.

Lincoln, G.A. \& Short, R.V. (1980). Seasonal breeding: Nature's contraceptive. Recent Prog. Horm. Res. 36: 1-52.

Lindsay D. R., Cognie Y., Pelletier J., Signoret J. P. (1975). Influence of the presence of rams on the timing of ovulation and discharge of LH in ewes. Physiol. Behav. 15: 423-426.

Liu C., Fukuhara C., Wessel I. J. H. (2004). Localization of Aanat mRNA in the rat retina by fluorescence in situ hybridization and laser capture microdissection. Cell Tissue Res. 315:197-201. 
Lozano J.M, Forcada F, Abecia J.A, (1998). Opioidergic and nutritional involvement in the control of luteinizing hormone secretion of postpartum Rasa Aragonesa ewes lambing in the mid-breeding season. Anim Reprod Sci. 52: 267-277.

Lunstra D.D, Christenson R.K. (1981). Fertilization and embryonic survival in ewes synchronized with exogenous hormones during the anestrous and estrous seasons. J Anim Sci. 53(2):458-66.

Mac Donnell H.F., Crowley, J.P. (1978). The Effect of Progesterone Impregnated Sponges on Fertility in Anoestrous Ewes. Veterinary Science Communications. 2:115-130.

Maina, D., Katz L. S. (1997). Exposure to a recently mated male increases ram sexual performance. Appl. Anim. Behav. Sci. 51:69-74.

Mallampati R.S, Pope A.L, Casida L.E. (1971). Effect of suckling on postpartum anestrus in ewes lambing in different seasons of the year. J. Anim. Sci. 32:673.

Malpaux B., Viguie C., Skinner D.C.,. Thiery J.C, Pelletier J., Chemineau P. (1996). Seasonal breeding in sheep: Mechanism of action of melatonin. Animal Reproduction Science. 42,109- 117.

Mandiki S.N.M., Bister J.L., Paquay R. (1990). Effects of suckling mode on endocrine control of reproductive activity resumption in Texel ewes lambing in July or November. Theriogenology. 33(2); 397- 413.

Martemucci G and D'Alessandro AG (2010). Estrous and fertility responses of dairy ewes synchronized with combined short term GnRH, PGF2 $\alpha$ and estradiol benzoate treatments. Small Ruminant Research. 93; 41-47. 
Martin, G.B., Oldham, C.M., Lindsay, D.R., (1980). Increased plasma LH levels in seasonally anovular Merino ewes following the introduction of rams. Anim. Reprod. Sci. 3: 125132.

Martin, G.B. ( 1984). Factors affecting the secretion of luteinizing hormone in the ewe. Biol. Rev. 59, 1-87.

Martin, G.M., Oldham, C.M., Cognie, Y., Pearce, D.T. (1986). The physiological responses of anovulatory ewes to the introduction of rams-a review. Live. Prod. Sci. 15: 219-247.

Martin, G.B., Walkden-Brown, S.W. (1995). Nutritional influences on reproduction in mature male sheep and goats. J. Reprod. Fertil. Suppl. 49, 437-449.

Mathews K., Haley M. (2015). Livestock, Dairy, and Poultry Outlook. USDA. Economic Research Service. http://www.ers.usda.gov/media/1783484/ldpm248.pdf.

Matton, P., Bhéreur, J., Dufour, J.J. (1977). Morphology and responsiveness of the two largest ovarian follicles in anestrous ewes. Can. J. Anim. Sci. 57, 459-464.

Mbayahaga J., Mandiki S. N. M., Bister J. L., Paquay R. (1998). Body weight, oestrus and ovarian activity in the local Burundian ewes and goats after parturition in the dry season. Anim. Reprod. Sci. 51(4):289-300.

McCracken JA. Glew ME, Scaramuzzi RI. (1970). Corpus luteum regression induced by prostaglandin F2 $\alpha$. J Clin Endocrinol Metab 30:544-547.

McCracken J.A., Carlson J.C., Glew M.E, Goding J.R., Baird D.T., Green K., Samuelsson B. (1972). Prostaglandin F2 $\alpha$ identified as a luteolvtic hormone in sheep. Nature (New Biology) 238:129-134.

McNeilly A.S (1994). Suckling and the control of gonadotropin secretion. In E. Knobil and J. eill (eds.). The physiology of Reproduction, Raven press, New York. 60: 1179 - 1212. 
McNeilly A.S (2001). Lactational control of reproduction. Reprod Fertil Dev. 13(7-8): 583- 589.

Menassol, J.B., Collet, A., Chesneau, D., Malpaux, B., Scaramuzzi, R. J. (2012). The interaction between photoperiod and nutrition and its effects on seasonal rhythms of reproduction in the ewe. Biol. Reprod. 86 (2): 52.

Mitchell L.M., King M.E., Aitken R.P, Wallace J.M. (1997). Influence of lambing date on subsequent ovarian cyclicity and ovulation rate in ewes. Anim. Sci. 65, 75-81

Molina A, Gallego L, Torres A, Vergara H, (1994). Effect of mating season and level of body reserves on fertility and prolificacy of Manchega ewes. Small Rum Res. 14: 209-217.

Morgan, P.D., Arnold, G.W., Lindsay, D.R., (1972). A note on the mating behaviour of ewes with various senses impaired. J. Reprod. Fertil. 30: 151-152.

Mormede, P., 1995. Le stress: interaction animal-homme-environnement. Cahiers Agric. 4, 275286.

Morrical DG, Youngs CR, McClain A. (1995). The influence of MGA and PG600 on the out of season reproductive performance of ewes. Anim Sci Leaflet. R1475.

Muir P.D., Smith N.B., Wallace G.J. (1989). Early lambing in Hawkes Bay: use of the ram effect. Proceedings of the New Zealand Society of Animal Production 49, 271- 275.

Nugent, R.A., Notter, D.R. (1990). Effect of cohabitation with white-faced ewes on estrous activity of Hampshire and Suffolk ewes exposed to rams in June. J. Anim. Sci. 68 : 15131519.

O’Callaghan, D., Donovan, A., Sunderland, S.J., Boland, M.P., Roche, J.F. (1994). Effect of the presence of male and female flockmates on reproductive activity in ewes. J. Reprod. Fertil. 100: 497-503. 
Oldham C. M., Martin G. B. (1978). Stimulation of the seasonally anovular Merinos ewes by rams. II. Premature regression of ram-induced corpora lutea. Anim. Reprod. Sci. 1: 291295.

Oldman C.M., Martin G.B., Knight T.W. (1979). Stimulation of seasonally anovular merino ewes by rams. I. Time from introduction of rams to the preovulatory LH surge and ovulation. Anim. Reprod. Sci. 1: $283-290$.

Oldham, C.M. (1980). Stimulation of ovulation in seasonally or lactationally anovular ewes by rams. Proc. Aust. Soc. Anim. Prod. 13: 73-74.

Oldham, C.M., Cognie, Y. (1980). Do ewes continue to cycle after teasing? Proc. Aust. Soc. Anim. Prod. 13: 82-85.

Oldham C. M., Thompson A. N., Ferguson M. B., Gordon D. J., Kearney G. A, Paganoni B. L. (2011). The birthweight and survival of Merino lambs can be predicted from the profile of liveweight change of their mothers during pregnancy. Animal Production Science. $51: 776-783$

Orgeur, P. and Signoret, J.P., 1984. Sexual play and its functional significance in the domestic sheep (Ouis aries L.). Physiol. Behav. 33: 11 1- 118

Orgeur P., Mavric N., Yvore P., Bernard S., Nowak R., Schaal B., Levy F. (1998). Artificial weaning in sheep: consequences on behavioural, hormonal and immuno-pathological indicators of welfare. Applied Animal Behaviour Science. 58; 87-103.

Ortavant, R., Pelletier, J., Ravault, J.P., lhimonier, J. and Volland-Nail, P. (1985). Photoperiod: main proximal and distal factor of the circannual cycle of reproduction in farm animals. Oxford Rev. Reprod. Biol. 7; 305-345. 
Ortavant, R., Bocquier, F., Pelletier, J., Ravault, J.P., Thimonier, J., Volland-Nail, P. (1988).

Seasonality of reproduction in sheep and its control by photoperiod. Aust. J. Biol. Sci. $41 ; 69-85$.

Parr, R.A. (1987). Overfeeding during early pregnancy reduces peripheral progesterone concentration and pregnancy rate in sheep. J. Reprod. Fertil. 80; 317-320.

Pardridge, W. M., Mietus, L. J. (1980) Transport of albumin-bound melatonin through the bloodbrain barrier. $J$ Neurochem. 34:1761-3.

Pearce D.T, Martin G.B, Oldham C.M (1985). Corpora lutea with a short life-span induced by rams in seasonally anovulatory ewes are prevented by progesterone delaying the preovulatory surge of LH. J Reprod Fertil. 75(1):79-84.

Pearce, G.P., Oldham, C.M. (1988). Importance of non-olfactory ram stimuli in mediating raminduced ovulation in the ewe. J. Reprod. Fertil. 84: 333-339.

Pelletier J., Almeida G. (1987). Short light cycles induce persistent reproductive activity in Ilede-France rams. J. Reprod. Fert., Suppl., 34: 215-226.

Perkins A., Fitzgerald J.A. (1994). The behavioral component of the ram effect: the influence of ram sexual behavior on the induction of estrus in anovulatory ewes. J. Anim. Sci. 72: 5155.

Platt T.E, Foster G.S, Tarnavsky G.K, Reeves J.J. (1983). Effects of photoperiod and estradiol on tonic gonadotropins in ovariectomized ewes. J Anim Sci. 56: 1180-1185.

Poindron P., Cognie Y., Gayerie F., Orgeur P., Oldham C. M., Ravault J. P. (1980). Changes in gonadotrophins and prolactin levels in isolated (seasonally or lactationally) anovular ewes associated with ovulation caused by the introduction of rams. Physiol. Behav. 25: $225-236$. 
Pope WF, McClure KE, Hogue DE, Day ML. (1989). Effect of season and lactation on postpartum fertility of Polypay, Dorset, St. Croix and Targhee ewes. J Anim Sci.67:116774.

Pretorius PS, Marincowitz G (1968). Post-natal penis development, testes descent and puberty in Merino ram lambs on different planes of nutrition. S Afr J Agric Sci.11: 319-334.

Price E.O, Katz L.S, Wallach S.J.R, Zenchak J.J. (1988). The relationship of male-male mounting to the sexual preferences of young rams. Appl. Anim. Behav. Sci. 21:347-355.

Price, E. O., D. Q. Estep, S. J. R. Wallach, and M. R. Dally. (1991). Sexual performance of rams as determined by maturation and sexual experience. J. Anim. Sci. 69:1047-1052.

Ragab M.T, Sharafeldin M.A, Khalil I.A (1966). Sexual behaviour of male lambs as affected by the plane of nutrition. J Anim Prod UAR. 6: 89-94.

Restall, B.J (1971). The effect of lamb removal on reproductive activity in Dorset Horn x Merino ewes after lambing. J. reprod. Fertil. 24;145.

Restall B. J. and. Starr B. G. (1977). The influence of season of lambing and lactation on reproductive activity and plasma LH concentrations in Merino ewes J. Reprod Fertil. 49;297-303.

Restall B.J, Kearins R.D, Herdegen J, Carberry P. (1978). The induction of reproductive activity in lactating ewes. Australian Journal of Agricultural Research 29(1) 181 - 187.

Robinson, T.J., (1967). Conclusions. In: T.J. Robinson (Editor), The control of the ovarian cycle in the sheep. Sydney University Press. 237-244.

Robinson, T.J. and Smith, J.F., (1967). The time of ovulation after withdrawal of SC-9880impregnated intravaginal sponges from cyclic merino ewes. In: T.J. Robinson (Editor), The control of the ovarian cycle in the sheep. Sydney University Press. 158-168. 
Robinson, T.J., Moore, N.W., Holst, P.J. and Smith, J.F. (1967). The evaluation of several progestagens administered in intravaginal sponges for the synchronization of oestrus in the entire cyclic merino ewe. In: T.J. Robinson (Editor), The control of the ovarian cycle in the sheep. Sydney University Press. 76-101.

Robinson, J.E., Radford, H.M. \& Karsch, F.J. (1985). Seasonal changes in pulsatile luteinizing hormone (LH) secretion in the ewe: relationship of frequency of $\mathrm{LH}$ pulses to daylength and response to estradiol negative feedback. Biol. Reprod. 33; 324-334.

Robinson J.J. (1996). Nutrition and reproduction. Anim. Reprod. Sci., 42: 25-34.

Roche, J.F., Foster, D.L., Karsch, F.J., Cook, B., Dziuk, P.J. ( 1970). Levels of luteinizing hormone in sera and pituitaries of ewes during the estrous cycle and anestrus. Endocrinology. 86; 568- 572.

Ronquillo J.C., Martínez A.P., Pèrez C.M.B., Sandoval B.F., Martin G.B., Valencia J., Sánchez J.G. (2008), Prevention of suckling improves postpartum reproductive responses to hormone treatments in Pelibuey ewes. Anim. Reprod. Sci. 107 ; 85-93.

Rosa H.J.D., Juniper D.T, Bryant M.J (2000). The effect of exposure to oestrous ewes on rams' sexual behaviour, plasma testosterone concentration and ability to stimulate ovulation in seasonally anoestrous ewes. Appl. Anim. Behav. Sci. 67:293-305.

Rosa, H.J.D., Bryant, M.J. (2002). The 'ram effect' as a way of modifying the reproductive activity in the ewe: a review. Small Ruminant Res. 45: 1-16.

Rosa H.J.D., M.J. Bryant (2003). Review: Seasonality of Reproduction in Sheep. Small Ruminant Research 48; 155-171.

Rubianes E, Ungerfeld R, (1993). Uterine involution and ovarian changes during early postpartum of autumn-lambing Corriedale ewes. Theriogenology 40: 365-372. 
Rubianes E, Ungerfeld R, Viñoles C, De Castro T, Carbajal B, Ibarra D, (1996). Uterine involution time in weaned and suckling ewes. Can J Anim Sci.16: 153-155.

Ryan J. P., Hunton J. R., Maxwell W. M. C. (1992). Time of ovulation in Merino ewes superovulated with PMSG and FSHP. Reprod. Fertil. Dev. 4:91-97.

Safranski T.J, Lamberson W.R, Keisler D.H(1992). Use of melengestrol acetate and gonadotropins to induce fertile estrus in seasonally anestrous ewes. J Anim Sci. 70:293541.

Scaramuzzi R.J., Campbell B.K., Downing J.A., Kendall N.R., Khalid M, Muñoz-Gutie'rrez M., Somchit A. (2006). A review of the effects of supplementary nutrition in the ewe on the concentrations of reproductive and metabolic hormones and the mechanisms that regulate folliculogenesis and ovulation rate-. Reprod Nutr Dev. 46: 339-354.

Scaramuzzi, R. J., Oujagir, L., Menassol, J. B., Freret, S., Piezel, A., Brown, H. M., et al. (2014). The pattern of LH secretion and the ovarian response to the 'ram effect' in the anoestrous ewe is influenced by body condition but not by short-term nutritional supplementation. Reprod. Fert. Dev. 28: 1154-1165.

Schanbacher B.B, Lunstra D.D. (1976). Seasonal changes in sexual activity and serum levels of LH and testosterone in Finnish Landrace and Suffolk rams. J Anim Sci. 43: 644-650.

Schichowski, C., E. Moors and M. Gauly (2010). Influence of weaning age and an experimental Haemonchus contortus infection on behaviour and growth rates of lambs. Applied Animal Behaviour Science. 125:103-108.

Schoenian, S. (2011). “A beginner's guide to raising sheep.” Sheep 201, December 2012. http://www.sheep101.info/201/ramrepro.html. 
Sefidbakht, N., Makarechian M., Ghorban K. (1971). A note on the effect of early weaning of lambs on reproductive rate of autumn lambed Karakul ewes. Anim. Prod. 13: 565.

Shevah Y., Black W.J.M., Carr W.R., Land R.B., (1974). The effect of lactation on the resumption of reproductive activity and the preovulatory release of LH in Finn $\times$ Dorset ewes. J. Reprod. Fertil. 38, 369-378.

Senger, P. L Pathways to Pregnancy and Parturition Pullman: Current Conceptions, Inc., 2003.

Signoret, J.P., Lindsay, D.R. (1982). The male effect in domestic mammals: effect on LH secretion and ovulation-importance of olfactory cues. In Olfaction and Endocrine Regulation, Ed. W. Breiphol. IRL Press, London. 63-70.

Signoret, J.P., Fulkerson, W.J., Lindsay, D.R. (1982). Effectiveness of testosterone-treated wethers and ewes as teasers. Appl. Anim. Ethol. 9: 37-45

Signoret, J.P. (1991). Sexual pheromones in the domestic sheep: importance and limits in the regulation of reproductive physiology. J. Steroid Biochem. Mol. Biol. 39: 639-645.

Silva L and Ungerfeld R (2006). Reproductive response in suckling Corriedale ewes to the ram effect during the non-breeding season: effect of postpartum condition and the use of medroxyprogesterone priming. Tropical Animal Health and Production 38; 365-369.

Simpson-Rastle, S.L., D’Souza, K.N., Baptiste, Q.S. and Knights, M. (2012). Effect of continuous suckling/ewe-rearing and supplementation on growth performance of Katahdin lambs. Joint Annual Meeting of the ADSA/ASAS Phoenix, AZ, USA, July 15-19, 2012. J. Anim. Sci. 90: (Suppl. 3):385.

Singh Knights D., Smith D., Knights M (2004). Forecasting models developed from West Virginia lamb sale transactions provide evidence of seasonality of slaughter and feeder lamb prices and a shifting market preference. J. Anim. Sci. Vol. 82: 114. 
Skinner D.C, Evans N.P, Delaleu B., Goodman R.L, Bouchard P., Caraty A.(1998).The negative feedback actions of progesterone on gonadotropin-releasing hormone secretion are transduced by the classical progesterone receptor. Proc Natl Acad Sci U.S. A. 95(18):10978-83.

Smart D., Singh I., Smith R.F., Dobson H. (1994). Opiods and suckling in relation to inhibition of oestradiol-induced LH secretion in postpartum ewes. Journal Reprod. Fert. 101: 115119.

Smith J.F., Cruickshank G.F, McGowan L.T., Parr J., Mortimer B.J. (1988). Seasonal changes in oestrus, ovulation and conception of Coopworth ewes treated with CIDRs and PMSG. Proc.N.Z.Soc.Anim.Prod.48:99-102.

Smith, J.F. (1991). A review of recent developments on the effect of nutrition on ovulation rate (the flushing effect) with particular reference to research at Ruakura. Proc. N. Z. Soc. Anim. Prod. 51, 15-21.

Spencer T.E, Burghardt R.C, Johnson G.A, Bazer F.W. (2004). Conceptus signals for establishment and maintenance of pregnancy. Anim Reprod Sci. 82-83:537-50.

Spencer TE, Johnson GA, Bazer FW, Burghardt RC, Palmarini M. (2007). Pregnancy recognition and conceptus implantation in domestic ruminants: roles of progesterone, interferons and endogenous retroviruses. Reprod Fertil Dev. 19(1):65-78.

Stellflug J.N, Hatfield P.G, Wulster-Radcliffe M.C, Walker J.W (2001). Reproductive performance of ewe lambs from ewes from different selection practices with or without induced estrus. Anim Reprod Sci. 66: 185-193. 
Thiéry, J.C., Martin, G.B., (1991). Neurophysiological control of the secretion of gonadotrophinreleasing hormone and luteinizing hormone in the sheep-a review. Reprod. Nutr. Dev. 3, 137- 173 .

Thiery J.C, Chemineau P., Hernandez X., Migaud M., Malpaux B. (2002). Neuroendocrine interactions and seasonality. Domestic animal Endocrinology. 23: 87-100.

Thomas G.B, Pearce D.T, Oldham C.M, Martin G.B, Lindsay D.R. (1988). Effects of breed, ovarian steroids and season on pulsatile secretion of LH in ovariectomized ewes. $J$ Reprod Fertil. 84:313-324.

Tritschler J.P 2nd, Duby R.T, Parsons E.M, Parsons M.J, Giordano D.J. (1991). Comparison of two progestogens during out-of-season breeding in a commercial ewe flock. Theriogenology. 35(5): 943- 952.

Ungerfeld R, Pinczak A, Forsberg M, Rubianes E. (1999). Response of Corriedale ewes to the "ram effect" after priming with medroxyprogesterone, fluorogestone, or progesterone in the non-breeding season. Acta Vet Scand. 40(4):299-305.

Ungerfeld R., Carbajala B., Rubianes E., Forsberg M. (2005). Endocrine and Ovarian Changes in Response to the Ram Effect in Medroxyprogesterone Acetate-primed Corriedale Ewes During the Breeding and Nonbreeding Season. Acta vet. scand. 46, 33-44.

Ungerfeld, R., Bielli, A. (2012). Seasonal and social factors affecting reproduction. Animal reproduction in livestock. Eolss Publishers Co. Ltd.

Ungerfeld R., Sanchez-Davila F. (2012). Oestrus synchronization in postpartum autumn-lambing ewes: effect of postpartum time, parity, and early weaning. Spanish Journal of Agricultural Research. 10(1): 62-68. 
Vecihi Aksakal, Muhlis Macit, Nurinisa Esenbuga, (2009). Effects of Various Ages of Weaning on Growth Characteristics, Survival Rate and Some Body Measurements of Awassi Lambs. Journal of Animal and Veterinary Advances, 8: 1624-1630.

Walton, J.S., McNeilly, J.R., McNeilly, A.S., Cunningham, F.J. (1977). Changes in concentration of follicle-stimulating hormone, luteinizing hormone, prolactin and progesterone in the plasma of ewes during the transition from anoestrus to breeding activity. J. Endocrinol. 75:127-136.

Warren J.E. Jr., Kiesling D.O., Akinbami M.A, Price E.A, Meredith S. (1989). Conception rates in early postpartum ewes bred naturally or by intrauterine insemination. J. Anim. Sci. 67: 2056-2059.

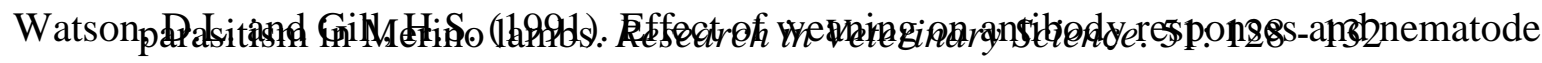

Watson, R.H., Radford, H.M. (1960). The influence of rams on onset of oestrus in Merino ewes in the spring. Aust. J. Agric. Res. 11: 65-71.

Webb, R., Gauld, I.K.( 1985). Genetics and physiology of follicle recruitment and maturation during seasonal anoestrus. In: Ellendorff, F., Elsaesser, F. (Eds.), Endocrine Causes of Seasonal and Lactational Anestrus in Farm Animals. Martinus Nijhoff, Lancaster. 19-28.

Welch R.A.S. (1983). Fertility of ewes treated with CIDR dispensers incorporating different levels of progesterone. Annual Report of Agricultural Research Division, New Zealand Ministry of Agriculture and Fisheries. 64. 
Welch, R.A.S., Andrewes, W.D., Barnes, D.R., Bremer, K., Harvey, T.G. (1984). CIDR dispensers for oestrus and ovulation control in sheep. In: Proceedings of the 10th International Congress on Animal Reproduction \& Artificial Insemination. Urbana, IL, USA.3: 354-355.

Wheaton J.E., Windels H.F., Johnston L.J. (1992). Accelerated lambing using exogenous progesterone and the ram effect. Journal of Animal Science. 70: 2628-2635.

Whiteman J.V, Zollinger W.A, Thrift F.A, Gould M.B (1972). Postpartum mating performance of ewes involved in a twice-yearly lambing program. Journal of Animal Science. 35: $836-842$.

Wildeus S. (2000). Current concepts in synchronization of estrus: Sheep and goats. J Anim Sci. $77: 1-14$

Windorski E.J., Schauer C.S., Wurst A.K, Inskeep E.K., Luther J.S (2009). Effects of melengestrol acetate and P.G. 600 on fertility in Rambouillet ewes outside the natural breeding season. Theriogenology. $70 ; 227-232$.

Wodzicka-Tomaszewska M, Hutchinson J.C.D, Bennett J.W. (1967). Control of the annual rhythm of breeding in ewes: effect of an equatorial daylength with reversed thermal seasons. J Agric Sci. 68: 61-67.

Wright, P.J., Geytenbeek, P.E., Clarke, I.J., and Hoskinson, R.M. (1989). The efficacy of ram introduction, GnRH administration, and immunization against androstenedione and oestrone for the induction of oestrus and ovulation in anoestrous post-partum ewes. Anim. Reprod.Sci. 21:237-247. 
Zaiem, I., D. Tainturier, J. ChemLi, and M. Soltani. 1996. Vaginal sponges and different PMSG doses to improve breeding performances of Black Thibar ewes. Rev. Med. Vet. 147:305310.

Zarco, L., Rodríguez, E.F., Angulo, M.R.B., Valencia, J. (1995). Female to female stimulation of ovarian activity in the ewe. Animal Reproduction Science. 39: 251-258.

Zarkawi, M., Al-Merestani, R., Wardeh, M.F. (1999). Induction of synchronized oestrous and early pregnancy diagnosis in Syrian Awassi ewes outside the breeding season. Small Rum. Res. 33: 99-102.

Zeleke M., Greyling J. P. C., Schwalbach L. M. J., Muller T., Erasmus J. A.( 2005). Effect of progestagen and PMSG on oestrous synchronization and fertility in Dorper ewes during the transition period. Small Ruminant Research, 56: 47-53.

Zenchak, J.J., Anderson, G.C., Scein, M.W. (1981). Sexual partner preference of adult rams (Ovis aries) as affected by social experiences during rearing. Appl. Anim. Ethol. 7: 157167.

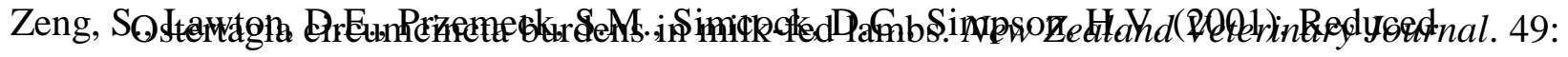
2-7 


\section{VITA}

\section{ABIODUN EMMANUEL ADEBIYI}

Birthplace

Ayede-Ekiti, Nigeria

Date of Birth.

December 27, 1987

\section{Schools Attended:}

St. Benedict's Catholic Primary School................... 1991 - 1996 Ayede-

Ekiti, Nigeria

Ayede Grammar School.

$1997-2003$

Ayede - Ekiti, Nigeria

Obafemi Awolowo University....

$.2005-2011$

Ile - Ife, Osun. Nigeria

West Virginia University

$.2013-2015$

Morgantown, WV

\section{Degreed Received:}

Bachelor of Agriculture in Animal Science

Obafemi Awolowo University, 2011

Master of Science in Reproductive Physiology

West Virginia University, 2015 